\title{
INTEGRATED QUANTITATIVE STRATIGRAPHY OF THE CENOMANIAN-TURONIAN BRIDGE CREEK LIMESTONE MEMBER USING EVOLUTIVE HARMONIC ANALYSIS AND STRATIGRAPHIC MODELING
}

\author{
STEPHEN R. MEYERS, ${ }^{1}$ BRADLEY B. SAGEMAN, ${ }^{1}$ AND LINDA A. HINNOV ${ }^{2}$ \\ ${ }^{I}$ Department of Geological Sciences, Northwestern University, Evanston, Illinois 60208, U.S.A. \\ ${ }^{2}$ Department of Earth and Planetary Sciences, The Johns Hopkins University, Baltimore, Maryland 21218, U.S.A.
}

\begin{abstract}
Secular changes in bulk sedimentation have a significant impact on the preservation of climatic signals in rhythmically bedded strata. In this study a quantitative cyclostratigraphic methodology is developed to use these signal distortions as a means to reconstruct sedimentation. The method exploits a moving-window Fourier technique that we designate "evolutive harmonic analysis" (EHA). We calibrate this methodology to a specific set of geologic conditions (i.e., changes in bulk sedimentation) using a series of stratigraphic models and then apply the technique to the Cenomanian-Turonian Greenhorn Formation of the Western Interior basin. Application of EHA to strata that preserve a record of orbital forcing allows the reconstruction of a high-resolution sedimentation history in which bulk sedimentation rates and hiatuses are quantified. Using the data on bulk sedimentation rate, rates of accumulation for geochemical proxies representing detrital, biogenic, and authigenic contributions to the sediment can be calculated. By integrating these quantitative assessments of siliciclastic dilution, primary production, and depositional redox conditions within a high-resolution chronostratigraphic framework, we are able to deconvolve secular trends in hemipelagic sedimentation during the Late Cenomanian-Early Turonian in the Western Interior basin. This integrated quantitative stratigraphic approach allows a reevaluation of hypotheses for the accumulation of excess organic matter in the Western Interior basin during the interval representing Oceanic Anoxic Event II.
\end{abstract}

\section{INTRODUCTION}

When orbital rhythms are preserved in a stratigraphic record they provide a chronometer that exceeds the resolution of any other relative or absolute dating method applicable to pre-Pleistocene sedimentary deposits. However, cyclostratigraphic reconstruction of the time-rock relationship in ancient deposits may be complicated by numerous factors, including: (1) inability to accurately constrain the periodicity of bedding rhythms due to lack of a local radiometric time scale (e.g., interbedded volcanic ashes), (2) instability of bedding frequencies due to sedimentation rate changes (especially within condensed sections, which are common in hemipelagic facies where many cyclic successions are preserved), (3) instability of bedding frequencies due to discontinuities in the sedimentary record (including depositional hiatuses and/or erosional loss of section), and (4) preservation of multiple orbital frequencies (i.e., precession, obliquity, and eccentricity), and changes in their relative dominance over time, which make simple methods of detection such as "bundle" counting difficult. Such factors have the potential to distort the stratigraphic expression of orbital periods significantly. Conversely, in cases where orbital influence can be quantitatively confirmed through time-series analysis techniques (e.g., spectral analysis), the astronomic chronometer provides a high-resolution tool with which to assess these factors not as distortions but as an important record of the sedimentation history. The resulting application of the orbital clock to the reconstruction of accumulation rates for sediment and sedimentary constituents represents a major advance in quantification and resolution of stratigraphic analysis.

Among the classic Mesozoic sections of rhythmically bedded strata upon which modern cyclostratigraphy has been built (e.g., Fischer 1980; Fischer et al. 1985; Barron et al. 1985; Herbert and Fischer 1986; Fischer 1991;
Schwarzacher 1987, 1994; Gale 1995; Weedon and Jenkyns 1999) the Cenomanian-Turonian Bridge Creek Limestone Member of the Greenhorn Formation, Western Interior U.S., has played a historic role. This unit, composed of limestone-marlstone bedding couplets, was one of the first deposits hypothesized to preserve Milankovitch orbital forcing (Gilbert 1895). Quantitative evidence for the presence of orbital periodicities within the Bridge Creek Limestone was recently recognized by Sageman et al. (1997) and Sageman et al. (1998) using numerical methods. Statistically significant frequencies were identified in the rhythmically bedded unit through application of spectral analysis techniques to lithologic, geochemical, and paleobiologic datasets (Sageman et al. 1997; Sageman et al. 1998). The assignment of orbital periodicities representing precession, obliquity, and eccentricity to the dominant spatial frequencies in the datasets was possible because of a high-resolution ${ }^{40} \mathrm{Ar}-{ }^{39} \mathrm{Ar}$ time scale (Obradovich 1993) derived from volcanic ashes interbedded within the study interval. However, the Sageman et al. $(1997,1998)$ study was restricted to a short time series representing only the upper Bridge Creek Limestone Member because of inferred sedimentation rate instability in the lower part of the unit.

This study has two major objectives. The first objective involves the development of a quantitative cyclostratigraphic method for the assessment of time-rock relationships in rhythmically bedded strata that: (1) is applicable to short stratigraphic series that preserve mixed orbital components (precession, obliquity, eccentricity); (2) permits quantitative identification of discontinuities in sedimentation (e.g. depositional hiatuses); and (3) utilizes the orbital signal preserved in strata to reconstruct high-resolution bulk sedimentation rates. The method was developed for the Bridge Creek Limestone in order to test and refine prior estimates of change in sedimentation rates. This unit provides an ideal test case for developing a new cyclostratigraphic technique because of the aforementioned internal time scale (Obradovich 1993), and the wealth of geologic data from the Western Interior basin against which a new bulk sedimentation rate reconstruction can be tested. The second objective of the study is a reevaluation of the dominant controls on hemipelagic sedimentation in the Bridge Creek Limestone through the application of cyclostratigraphically derived bulk sedimentation rates to select biogeochemical parameters (calculation of elemental and compound accumulation rates).

The methodology we use to reconstruct sedimentation rates (evolutive harmonic analysis, or EHA) is developed in tandem with stratigraphic modeling experiments. We apply this methodology to a new high-resolution optical densitometry data set from the U.S.G.S. \#1 Portland core to produce the sedimentation reconstruction. We then use this sedimentation history to calculate accumulation rates for a set of geochemical parameters measured in the same core. This integration of quantitative cyclostratigraphic methods with biogeochemical analysis represents a significant advance for stratigraphic studies of hemipelagic sedimentation, especially those representing geologic intervals of enhanced burial of organic carbon where the relative roles of dilution, productivity, and preservation remain poorly differentiated. Because the Late Cenomanian-Early Turonian Oceanic Anoxic Event II (Schlanger and Jenkyns 1976), hypothesized from the carbon isotopic record to reflect a global productivity event (Arthur et al. 1987), corresponds with the lower Bridge Creek Limestone there is an unparalleled opportunity to evaluate the effectiveness of this integrated quantitative stratigraphic approach. 


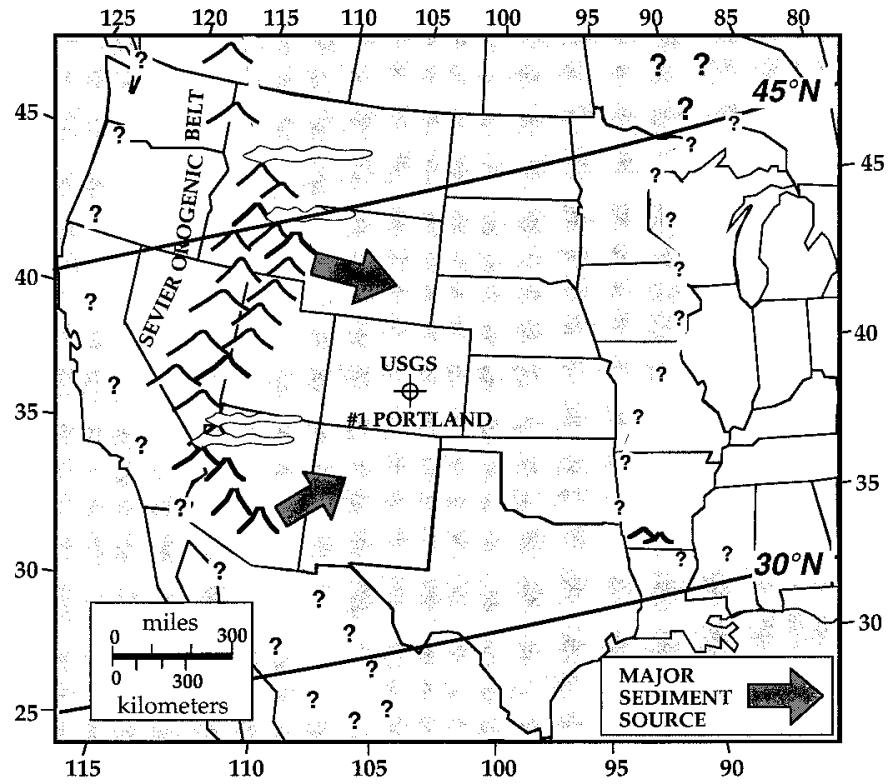

FIG. 1.-Paleogeographic map of Western Interior Seaway during Early Turonian peak highstand (flooded areas shaded; inferred boundaries queried) superimposed on U.S.A. transverse mercator projection with present-day latitude and longitude on borders. Location of U.S.G.S. \#1 Portland core, $30^{\circ}$ and $45^{\circ}$ paleolatitude lines, Sevier Orogenic Belt, and major sediment sources are indicated (modified from Sageman and Arthur 1994; Roberts and Kirschbaum 1995).

\section{GEOLOGICAL BACKGROUND}

The Bridge Creek Limestone Member of the Greenhorn Formation was deposited during Late Cenomanian-Early Turonian time in the Western Interior basin, an elongate foreland-style depression that formed during the Late Jurassic and Cretaceous east of the uplifted Sevier orogenic belt (Fig. 1) (Kauffman and Caldwell 1993). A combination of foreland subsidence related to the Sevier Orogeny and global tectonoeustasy was responsible for marine flooding and accumulation of a thick sedimentary sequence in this broad epicontinental trough (Kauffman 1977, 1985; Hancock and Kauffman 1979; Kauffman and Caldwell 1993). The Bridge Creek Limestone Member records one of the maximum highstands of sea level within this record, as indicated by the character and widespread distribution of its lithofacies and biofacies, as well as the location of its coeval paleoshorelines (Elder 1985; Sageman and Arthur 1994). It reflects the apex of water depth, detrital starvation in the distal basin, and northward influence of coccolithophore-bearing marine waters that originated in the Tethys Sea to the south (Kauffman 1977, 1984; Kauffman and Caldwell 1993).

The Bridge Creek Limestone Member is the uppermost member of the Greenhorn Formation, underlain by calcareous shales of the Hartland Shale Member and overlain by the Fairport Chalky Shale Member of the Carlile Formation (Fig. 2). It is chiefly composed of decimeter-scale couplets of hemipelagic marlstone and limestone that are laterally traceable for over $1000 \mathrm{~km}$ in the basin (Hattin 1971; Elder et al. 1994). In general, the couplets are characterized by an alternation from darker, clay- and organiccarbon-rich, laminated to slightly burrowed mudrock facies to lighter, carbonate-rich and organic carbon-poor, bioturbated limestone facies. These features are quantified for the USGS \#1 Portland core in Figure 2 (for location see Fig. 1) and have been described in detail by Sageman et al. (1997) and Sageman et al. (1998). Secular variations in this high-frequency alternation include increase in carbonate and organic carbon contents of clay-rich hemicycles from the lower to upper Bridge Creek Limestone, accompanied by the common appearance of calcarenitic lenses and beds in the upper 4 meters of the study interval (Fig. 2). With the exception of a zone from about 3.5 to $5.5 \mathrm{~m}$ above the base of our measured section (Fig.
2), the organic-carbon content of clay-rich hemicycles in the lower Bridge Creek Limestone is anomalously low, especially considering that this interval coincides with Oceanic Anoxic Event II (OAE II) as indicated by the positive excursion in carbon isotope values documented by various workers (Pratt 1985; Arthur et al. 1988; Hayes et al. 1989). Through the rest of this paper, subsections of the study interval will be referred to using "lower" (0 to $6 \mathrm{~m})$ and "upper" (6 to $12 \mathrm{~m})$ member subdivisions, in terms of position within the OAE II interval (TOC-poor zone, 0 to $3.5 \mathrm{~m}$, vs. TOC-rich zone, 3.5 to $5.5 \mathrm{~m}$ ), or using the well-established ammonite biozones of Cobban (1985, 1993) (Fig. 2).

Although the results of Sageman et al. (1997) and Sageman et al. (1998) provided new evidence bearing on Bridge Creek sedimentation, the mechanisms responsible for the formation of the marlstone-limestone couplets remain poorly understood. Alternate hypotheses that have been proposed include variations in pelagic productivity related to orbitally forced changes in sea-surface conditions and/or circulation (Eicher and Diner 1989; Watkins 1989) as well as cyclic variations in siliciclastic dilution resulting from Milankovitch forcing of the northern hemisphere hydrologic cycle (Barron et al. 1985; Arthur and Dean 1991; Pratt et al. 1993). From spectral analysis of $\% \mathrm{TOC}$ and $\% \mathrm{CaCO}_{3}$ records from the Bridge Creek Limestone, Sageman et al. (1997) and Sageman et al. (1998) proposed a new model that incorporated both of these mechanisms. In this hypothesis, siliciclastic dilution controlled by mid- to high-latitude fluctuations in the hydrologic cycle varied constructively and destructively with pelagic productivity cycles reflecting changes in low-latitude (Tethyan) sea-surface conditions. Differences in the observed frequencies recorded by the two parameters was hypothesized to reflect variable influence of obliquity vs. precession across latitude.

\section{METHODS}

\section{Evolutive Harmonic Analysis}

Evolutive harmonic analysis (EHA) is a time-frequency technique that can identify temporal changes in the dominant frequencies preserved in cyclic stratigraphic sections. In relatively short hemipelagic stratigraphic successions the most likely cause of instabilities (abrupt shifts or "drifting'") in the spatial bedding frequencies is a change in sedimentation. This includes changes in the supply of one or more sedimentary constituents (resulting in changes in bulk sedimentation rate), cessation of sedimentation (hiatuses), and removal of sediment (erosional events). EHA may be utilized to assess sedimentation rate changes whenever periodic forcing phenomena can be readily identified (i.e., orbital forcing, annual varving, etc.).

The EHA procedure used in this study analyzes stratigraphic data series by performing multi-taper method (MTM) harmonic analysis (Thompson 1982) on a moving data window that is shifted sequentially through the study interval. MTM harmonic analysis was used because it has exceptional frequency resolution in very short and noisy time series and provides a test of statistical significance (F-variance ratio test) for each frequency component (see Appendix A). Furthermore, this test of significance is independent of the amplitude of the periodic component, thus the method has the additional quality of identifying certain low-amplitude peaks that may be statistically significant as well as indicating which high-amplitude peaks may not be statistically significant. Moving-window MTM techniques have previously been used for stratigraphic analysis by a number of researchers (Birchfield and Ghil 1993; Yiou et al. 1991; Park and Herbert 1987; Hinnov et al. 2000).

The critical parameters for the MTM evolutive harmonic analysis include the type of data tapers used (known as discrete prolate spheroidal sequences or DPSS), and the size of the moving window. Tapering of the data series presents a compromise between the statistical stability of the Fourier estimate and the frequency resolution. Likewise, the size of the moving window is a compromise between the maximum resolution of the target sedimentation rates and the maximum frequency resolution. Ideally, one uses 


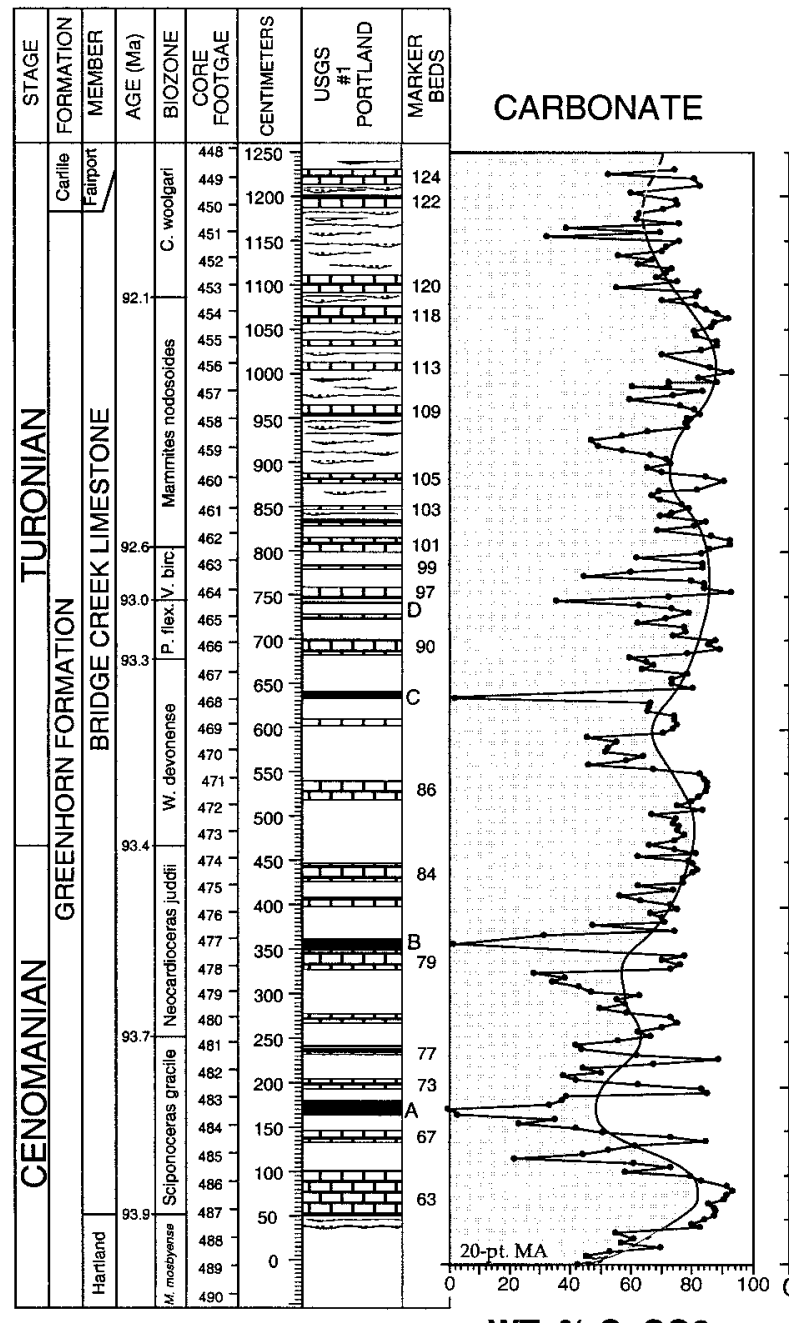

WT. \% $\mathrm{CaCO} 3$
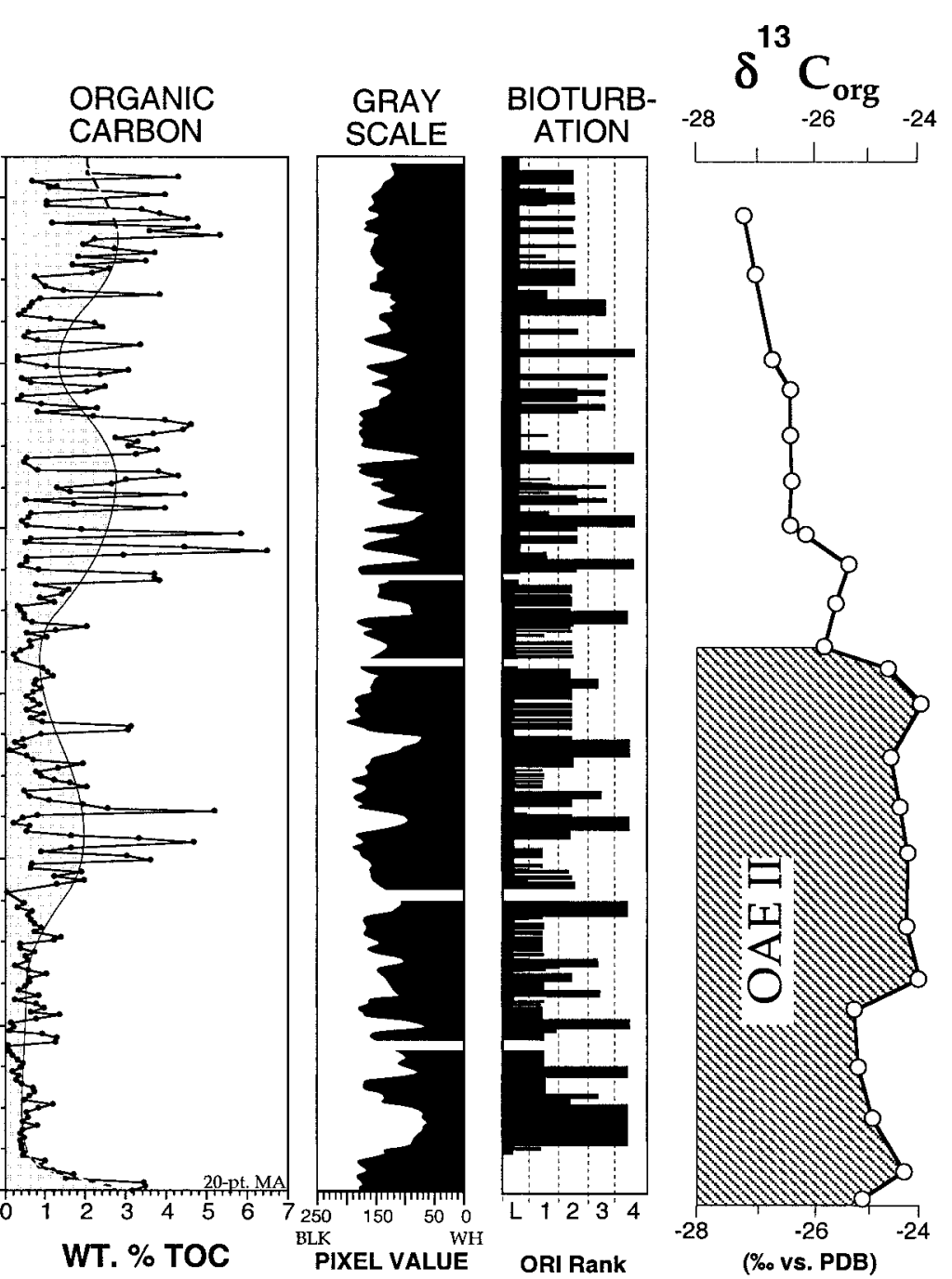

FIG. 2.-Detailed stratigraphy of the Bridge Creek Limestone Member in the U.S.G.S. \#1 Portland core with plots of weight percent calcium carbonate and total organic carbon (\% $\mathrm{CaCO}_{3}, \%$ TOC: smooth lines are 20-point moving averages), optical densitometry (average pixel values from core photographs), oxygen-related ichnocoenosis (ORI) ranks from Savrda (1998), and $\delta^{13} \mathrm{C}_{\mathrm{org}}$ values (Pratt 1985). Correlation of the \#1 Portland core to the Rock Canyon Anticline reference section is indicated by the numbered marker limestone beds of Cobban and Scott (1972) and the lettered marker bentonites of Elder (1985). The biozonation is from Kennedy and Cobban (1991), and the biozone boundary ages represent an interpolated time scale (Kauffman et al. 1993) based on radiometric dating of bentonites by Obradovich (1993).

the highest-resolution tapers and the minimum window size that will still permit tracking of statistically significant orbital components.

The application of this high-resolution harmonic methodology, rather than the more common (but lower-resolution) MTM "power" spectral analysis (see Thomson 1982 for discussion of the distinction), was necessary because of the extremely short data windows analyzed in this study ( 2 meters, representing $<400 \mathrm{kyr}$ ). This small window size was required for reconstruction of a high-resolution sedimentation history in a stratigraphic record representing $<2 \mathrm{Myr}$ of hemipelagic deposition. In addition to the assessment of sedimentation rate changes, the EHA method allows for quantitative recognition of hiatuses and other aspects of the sedimentation history. These characteristics of the EHA method are addressed further in the following section.

\section{Frequency Expression of Stratigraphic Perturbations}

Of particular value to the stratigraphic analysis of orbitally forced sedimentation is the fact that stratigraphic perturbations (i.e., sedimentation rate changes, hiatuses, etc.) have diagnostic expressions in the frequency domain. To illustrate these effects, a number of stratigraphic models were generated (Figure 3). The modeling exercises begin with the creation of simple uni-frequency time-domain models to simulate insolation forcing by an orbital periodicity (e.g., precession). The initial time-domain expressions were generated with amplitudes of unity in order to represent generalized (unitless) geochemical or lithologic variables that respond linearly to orbital forcing. These orbital forcing expressions (denoted here as $x_{\text {inso }}$, a function of time) were sampled every thousand years and then converted to the spatial domain (here denoted $y_{a c c}$, the spatial location of $x_{\text {inso }}$ at time $t$ ) to create sediment accumulation records. To perform harmonic analysis, the resultant spatial series were then resampled at an evenly spaced interval of $0.01 \mathrm{~m}$. All harmonic analyses were conducted on 2meter windows to maintain a comparable frequency resolution between models. The MTM harmonic analyses of the stratigraphic models used three $2 \pi$-DPSS (high-resolution) data tapers.

Figure 3A displays model results for hiatus expression in the frequency domain. A 10 kyr hiatus (at 1 meter) was applied to a $20 \mathrm{kyr}$ periodic signal, deposited with a background sedimentation rate of $1 \mathrm{~cm} / \mathrm{kyr}$. The frequency domain expression of this stratigraphic perturbation is a bifur- 
cation of the original frequency ( $20 \mathrm{kyr}$ at 5 cycles/m) into two new frequencies ( $22 \mathrm{kyr}$ at $4.5 \mathrm{cycles} / \mathrm{m}$ and $18 \mathrm{kyr}$ at $5.5 \mathrm{cycles} / \mathrm{m})$. Note that the bifurcation caused by this discontinuity in sedimentation displays two peaks that are equidistant from the original unperturbed frequency. In finegrained, mud-rich sediments where breaks in sedimentation are rarely obvious, this frequency domain expression may be one of the most effective methods for their detection.

Figure $3 \mathrm{~B}$ displays results for a modeled sedimentation-rate increase. Sedimentation-rate increases cause the elongation (or stretching) of the sinusoid, whereas sedimentation-rate decreases result in the compression of the sinusoid in the spatial domain. A modeled sedimentation rate of $2 \mathrm{~cm} /$ kyr results in a shift from 5 cycles/m (the original spatial frequency at 1 $\mathrm{cm} / \mathrm{kyr}$ ) to 2.5 cycles $/ \mathrm{m}$.

Two general types of nonperiodic stratigraphic disturbance or "noise", can affect the preservation of orbital periodicities. These include amplitude noise and frequency noise. In order to illustrate the effect that a nonperiodic sedimentation event (such as random addition of volcanic ash, which would affect both optical densitometry and geochemical data series) would have when superposed on a periodic stratigraphic signal, we applied random additive amplitude noise. Although such nonperiodic sedimentation events may also generate frequency noise, we chose to model these phenomena independently so as to address their unique contributions. The random signal applied in this experiment had a maximum value equivalent to $500 \%$ of the variance of the primary periodic input signal, which was a $20 \mathrm{kyr}$ periodicity with an amplitude of unity, deposited at a rate of $1 \mathrm{~cm} / \mathrm{kyr}$ (Fig. 3C). This random amplitude noise in the spatial domain raised the background amplitude, but the primary frequency was preserved. Thus, unless noise levels far exceed the primary signal, detection of the latter using EHA is robust.

Similarly, random additive and subtractive frequency noise was applied to a $20 \mathrm{kyr}$ periodic signal with a background sedimentation rate of $1 \mathrm{~cm} /$ kyr (Fig. 3D) in order to test the robustness of the MTM harmonic method to rapid additions of sediment and/or random scouring events (i.e., associated with storms, turbidity currents, volcanism, etc.). In two modeling experiments, random disturbances of up to $5 \mathrm{~mm}$ and $2 \mathrm{~cm}$, respectively, were generated every kyr (the original sampling interval of $x_{\text {inso }}$ ). At a background sedimentation rate of $1 \mathrm{~cm} / \mathrm{kyr}$, a $50 \%$ perturbation $(5 \mathrm{~mm})$ caused little displacement of the primary frequency and little complication of the spectra. Only when the maximum spatial disturbance greatly exceeded the value of bulk sedimentation (i.e., $2 \mathrm{~cm} / \mathrm{kyr}$ when the background sedimentation rate is $1 \mathrm{~cm} / \mathrm{kyr}$, or $200 \%$ of sedimentation rate) did frequency noise result in severe complication of the spectrum (Fig. 3D).

In order to investigate nonlinearity in the relationship between the temporal orbital periodicity and the preserved spatial sedimentary signal, and the effects of this on estimation of frequency content in alternating clayand carbonate-rich facies, differential compaction was modeled as

$$
y_{a c c}(t+1)=y_{a c c}(t)+\Delta d \cdot(1-c(t+1))
$$

with a simple linear transformation of $x_{\text {inso }}$ to compaction

$$
c(t+1)=m \cdot x_{\text {inso }}(t+1)+b
$$

where $y_{a c c}$ is the total accumulated thickness at time $t\left(y_{a c c}=0\right.$ at $\left.t=0\right)$, $\Delta \mathrm{d}$ is the depth increment of the series (background sedimentation rate times temporal increment of the series), $c$ is the percent compaction, and $m$ and $b$ are the slope and $y$ intercept respectively, calculated so that the maximum and minimum values of $x_{\text {inso }}$ are transformed into the maximum and minimum desired compaction. In principle, if carbonate content is controlled by factors that vary according to the orbital periods, and the degree of sediment compaction scales to $\mathrm{CaCO}_{3}$ content (an oversimplified but reasonable approximation; see Ricken 1994), then the variance in compaction should also track the orbital signal. But how does this influence the spectral estimation of frequency content in the compacted strata? For this model a time series with a $40 \mathrm{kyr}$ periodic signal and a background sedimentation rate of $1 \mathrm{~cm} / \mathrm{kyr}$ was generated (Fig. 3E). The upper and lower limits for degree of compaction in the model were selected as $80 \%$ (mudrich hemicycle) and 30\% (carbonate-rich hemicycle) on the basis of Ricken's (1994) study of Bridge Creek limestone-marlstone couplets. The impact of differential compaction is a squeezing of the peaks (mud-rich hemicycle) and broadening of the troughs (carbonate rich-hemicycle) in the primary signal (Fig. 3E), resulting in a shift of the input peak to a higher frequency in the spectral estimate and a corresponding decrease in the final measured sedimentation rate to $0.45 \mathrm{~cm} / \mathrm{kyr}$ (due to thinning of the spatial series). With this effective sedimentation rate (or $S_{\mathrm{e}}$, not corrected for compaction) the calculated periodicity is correctly estimated at $40 \mathrm{kyr}$. The main consequence of compactional nonlinearity is spectral leakage and the generation of harmonics (Fig. 3E).

Differential accumulation was modeled as

$$
y_{a c c}(t+1)=y_{a c c}(t)+\Delta d+k \cdot x_{i n s o}(t+1)
$$

where $k$ is the maximum magnitude of accumulation variability around a base sedimentation rate (recall that $x_{\text {inso }}$ has been generated to vary between -1 and 1 ), and the other variables are identical to those indicated in the compaction model. The purpose of this model was to investigate the frequency expression of accumulation rate variability on the lithologic couplet scale. A series with a $40 \mathrm{kyr}$ periodic signal and an average sedimentation rate of $1 \mathrm{~cm} / \mathrm{kyr}$ was generated, but this sedimentation rate was forced to vary between $1.5 \mathrm{~cm} / \mathrm{kyr}$ and $0.5 \mathrm{~cm} / \mathrm{kyr}$ in association with the amplitude of the signal (Fig. 3F). Note that the primary frequency is preserved, but this differential accumulation on the scale of couplets also results in spectral leakage and the generation of harmonics. Although the stratigraphic distortions associated with differential compaction and differential accumulation appear to have minor impact on spectral frequency estimates, we also conjecture that they could partially or wholly offset each other if lithologic couplets were characterized by alternation of faster accumulationhigher compaction hemicycles with slower accumulation-lower compaction hemicycles. Certainly, much more complicated stratigraphic models than those presented here can be devised, and the reader is referred to similar modeling approaches in Schiffelbein and Dorman (1986), Herbert (1987, 1994), and Ripepe and Fischer (1991).

\section{Geochemical Analytical Methods}

Samples from the U.S.G.S. \#1 Portland core, provided by Dean and Arthur (1998) as part of a multi-disciplinary subsurface study of the Western Interior basin, were crushed to $<200$ mesh $(<0.074 \mathrm{~mm})$. Standard coulometric techniques (Huffman 1977) were used to determine $\% \mathrm{CaCO}_{3}$ and $\%$ TOC values. The range of error associated with coulometric analysis is typically less than $1 \%$ of the carbon present. Concentrations of $\mathrm{Ti}, \mathrm{Al}$, $\mathrm{Na}, \mathrm{K}, \mathrm{Fe}$, and $\mathrm{Mg}(\%)$, as well as Mo (ppm), were determined using inductively coupled plasma spectroscopy (Lichte et al. 1987). From analysis of blind duplicates and standards, the average error for ICP analyses ranged from 2 to $5 \%$, depending on the element analyzed.

\section{Development of High-Resolution Sedimentation Rates for the Bridge Creek Limestone}

In order to create a Bridge Creek grayscale record, black-and-white photographs of the slabbed archive half of the \#1 Portland core taken under uniform conditions at the U.S.G.S. Core Research Center were scanned to 8-bit TIFF files and analyzed for optical densitometry using image-analysis software (NIH Image). The software performs a grayscale analysis of the rock, with values ranging from 0 (white) to 255 (black). The advantage of this data set is that it has a very fine sampling resolution, placing the Nyquist frequency (maximum frequency resolvable) far above that of most 

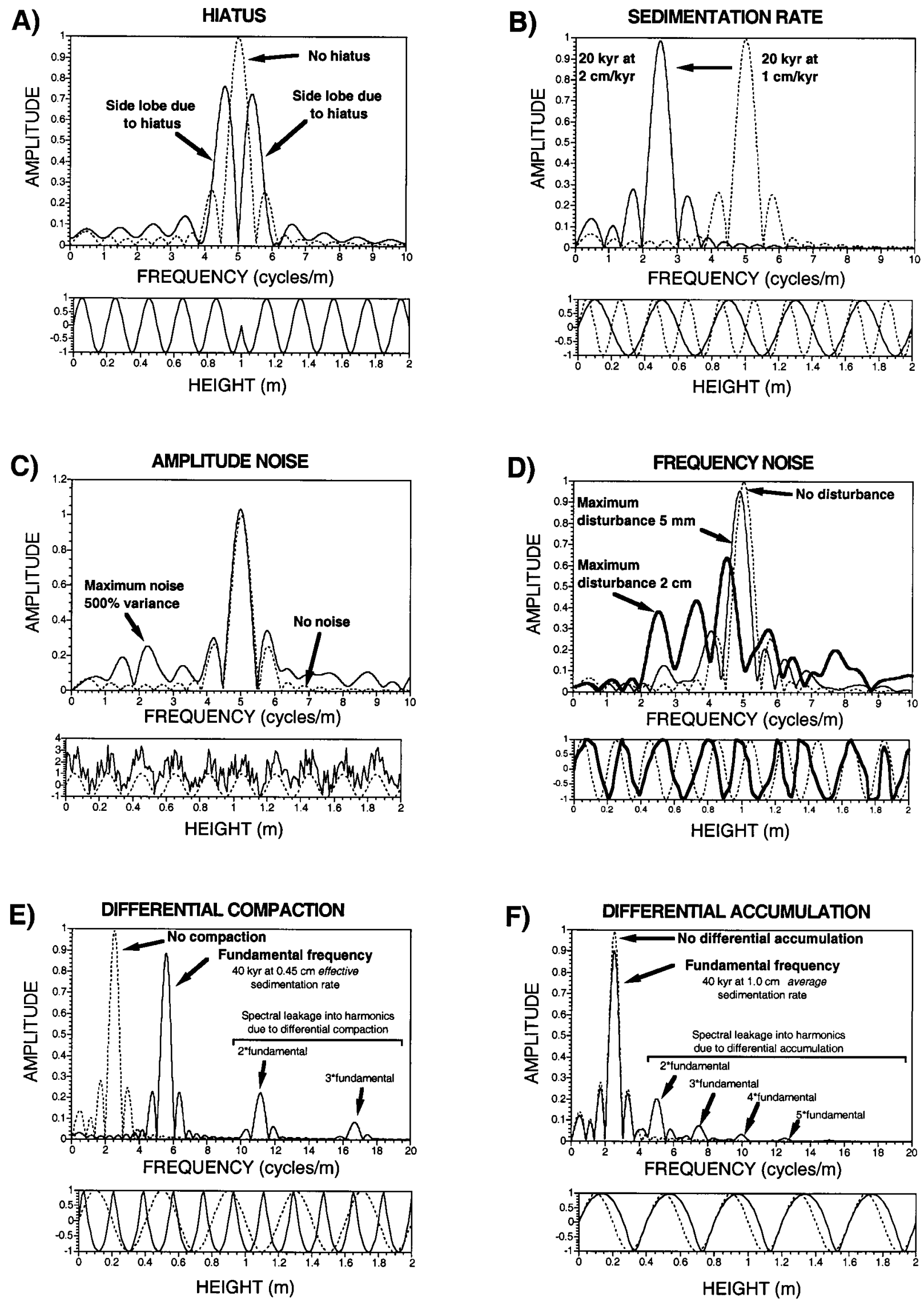
TABLE 1.-Radiometric dates of Obradovich (1993).

\begin{tabular}{ccccc}
\hline \hline Bentonite ID & $\begin{array}{c}{ }^{40} \mathrm{Ar}-{ }^{39} \mathrm{Ar} \text { Date } \\
(\mathrm{Ma})\end{array}$ & $\begin{array}{c}\text { Average Age } \\
(\mathrm{Ma})\end{array}$ & $\begin{array}{c}\text { Height in Core } \\
(\text { meters })\end{array}$ & $\begin{array}{c}\text { Bentonite } \\
\text { Thickness } \\
(\mathrm{cm})\end{array}$ \\
\hline $\mathrm{A}$ & $93.90 \pm 0.72$ & $93.70 \mathrm{Ma} \pm 1.14$ & 1.62 & 17 \\
& $93.49 \pm 0.89$ & & & 14 \\
$\mathrm{~B}$ & $93.78 \pm 0.49$ & $93.56 \mathrm{M} \pm 0.86$ & 3.36 & \\
& $93.59 \pm 0.58$ & & & 11.5 \\
$\mathrm{C}$ & $93.30 \pm 0.40$ & - & 6.03 & 2.5 \\
$\mathrm{D}$ & $93.25 \pm 0.55$ & - & 7.03 & \\
\hline \multicolumn{7}{l}{ Height in core is corrected for the removal of the bentonites. }
\end{tabular}

other lithologic or geochemical data series. This prevents frequencies from outside the band of interest (here the Milankovitch band) from aliasing-in and causing spurious peaks. The data set generated for this study was sampled at a resolution of $<0.7 \mathrm{~mm}$, which places the Nyquist frequency at $>7.14$ cycles/centimeter. Prior to analysis, data points representing four bentonites were removed from the time series (Table 1). These deposits represent geologically instantaneous events of deposition, and generate both frequency and amplitude noise (the rapid addition of sediment from volcanic activity distorts the frequency, and the light color distorts the amplitude).

In the Bridge Creek Limestone Member, optical densitometry values provide a reasonable proxy for geochemical alternations associated with the bedding couplets. In general, changes in grayscale values reflect changes in $\% \mathrm{CaCO}_{3}$, but the relationship may be influenced by additional sedimentary components, such as light-colored bentonitic clay or dark-colored iron sulfides associated with enhanced accumulation of organic matter. The relationship between grayscale and carbonate is best developed in the upper Bridge Creek Limestone, where the couplets are dominated by limestonemarlstone alternations (Fig. 4A). A few samples suggest a change in the relationship as carbonate content decreases below about 60 to 50\%. This change is even better illustrated by data from the lower part of the study interval. Here a higher proportion of limestone-calcareous shale couplets produces a more pronounced "bend" in the cross-plot (Fig. 4B) because changes in grayscale become more poorly correlated to changes in carbonate content once $\% \mathrm{CaCO}_{3}$ values fall below 60 to $50 \%$. In addition, some of the data points in Figure 4B are characterized by anomalously low grayscale values for their measured carbonate content, falling completely off the "'dogleg"' trend. In these cases the addition of lighter-colored bentonitic clay, typically through bioturbation, resulted in the lower $\% \mathrm{CaCO}_{3}$ and lower color values. The explanation for loss of correlation at $\% \mathrm{CaCO}_{3}$ values below 60 to $50 \%$ is suggested by cross-plots of \% TOC and grayscale (Figs. 4C, D). In samples with \% TOC values greater than about 1.5 (i.e., marlstones and calcareous shales), the darkening effect of iron sulfides formed during early diagenesis of organic-rich sediment appears to damp out color changes. In a few cases from the upper Bridge Creek Limestone
Member (Fig. 4C) samples with enhanced organic-carbon content showed anomalously low grayscale values. These represent marlstones in which the darkening due to organic matter associated with Fe-sulfides is offset by elevated carbonate content.

The implication of these observations for application of EHA to the grayscale data set is as follows. (1) Bentonite-contaminated samples could introduce amplitude and frequency noise to the spectrum. However, given their low number and the fact that they typically constitute only one or two samples on the curve from a carbonate-rich to a clay-rich end member, their impact would be significantly below the threshold for distortion indicated by modeling results. (2) The "dogleg" pattern of correlation has little implication for the frequency content of the data series but could imply the introduction of some amplitude distortion. Again, however, our modeling results suggest that amplitude variations of this magnitude would not obscure the primary signal. (3) Overall, the relationship between grayscale variance and changes in carbonate (vs. clay) content within couplets is not compromised by the damping effect of organic matter on color. Therefore, the grayscale data set provides an excellent high-resolution record of compositional changes in the bedding couplets.

\section{Calibration of the EHA Method}

In order to calibrate our EHA analysis of the Bridge Creek Limestone to the time-frequency response of sedimentation perturbations we first performed evolutive harmonic analysis on synthetic models. The model result shown in Figure 5 begins with an insolation series calculated for 3.0 Myr to $0.5 \mathrm{Myr}$ (using Analyseries (Paillard et al. 1996) with the solution of Laskar (1990)) at 40 degrees N (approximate paleolatitude in the Cretaceous Western Interior Seaway) during the northern hemisphere winter solstice. MTM harmonic analysis of this insolation series indicates a dominant obliquity component at $41.03 \mathrm{kyr}$, and dominant precession amplitudes at $23.70 \mathrm{kyr}, 22.38 \mathrm{kyr}$, and $18.99 \mathrm{kyr}$. The insolation series was linearly transformed into optical densitometry data (varying between 0 and 255) to emulate a sediment accumulation record. This accumulation record was generated to include a $25 \mathrm{kyr}$ hiatus at 3 meters, a gradual linear sedimentation rate increase $(0.8 \mathrm{~cm} / \mathrm{kyr}$ to $1.0 \mathrm{~cm} / \mathrm{kyr})$ from 6 to 10.5 meters, and a rapid sedimentation drop $(1.0 \mathrm{~cm} / \mathrm{kyr}$ to $0.6 \mathrm{~cm} / \mathrm{kyr})$ at 14.5 meters. In the final step, EHA using three $2 \pi$ (high-resolution) tapers and a 2-meter (200-333 kyr) moving window with a $0.05 \mathrm{~m}$ increment was applied to this synthetic record to produce the time-frequency plot in Figure 5.

The hiatus at 3 meters is clearly expressed as a bifurcation of the obliquity peak $(\mathrm{O} 1=41 \mathrm{kyr})$. In contrast, regularly occurring bifurcations in the precession band are not due to discontinuities in sedimentation but are a consequence of the small size of the moving window. Because the amplitudes and frequencies of the precessional components are modulated by the longer-period eccentricity components, when the eccentricity is high the variance of the precessional components is maximized and all three of

$\leftarrow$

FIG. 3.-Simple models for the frequency domain expression of common stratigraphic perturbations. Each of the modeling experiments is characterized by a frequency domain (amplitude) plot and a spatial (or stratigraphic) domain plot. The periodic signals were generated with amplitudes of unity. All harmonic analyses were conducted on 2-meter windows with three $2 \pi$-DPSS data tapers, to maintain a comparable frequency resolution between the models. In experiments A-D, a dashed line denotes a $20 \mathrm{kyr}$ periodic signal converted to the spatial domain using a sedimentation rate of $1 \mathrm{~cm} / \mathrm{kyr}$. In experiments $\mathrm{E}$ and $\mathrm{F}$, a dashed line denotes a $40 \mathrm{kyr}$ periodicity converted to the spatial domain using a sedimentation rate of $1 \mathrm{~cm} / \mathrm{kyr}$. A) A $10 \mathrm{kyr}$ hiatus (at 1 meter) was applied to a $20 \mathrm{kyr}$ periodic signal, with a background sedimentation rate of $1 \mathrm{~cm} / \mathrm{kyr}$. B) A $20 \mathrm{kyr}$ periodic signal was modeled with a sedimentation rate of $2 \mathrm{~cm} / \mathrm{kyr}$. C) Random additive amplitude noise with a maximum value equivalent to $500 \%$ of the variance of the signal was generated and applied to a $20 \mathrm{kyr}$ periodic signal, with a background sedimentation rate of $1 \mathrm{~cm} / \mathrm{kyr}$. D) Random additive and subtractive frequency noise was applied to a $20 \mathrm{kyr}$ periodic signal, with a background sedimentation rate of $1 \mathrm{~cm} / \mathrm{kyr}$. In two separate scenarios, random disturbances of up to $5 \mathrm{~mm}$ and $2 \mathrm{~cm}$ were generated every thousand years. E) A $40 \mathrm{kyr}$ periodic signal with background sedimentation rate of $1 \mathrm{~cm} / \mathrm{kyr}$ was generated. This series was differentially compacted with a maximum value of $80 \%$ for the clay-rich hemicycle and a minimum compaction value of $30 \%$ representing the carbonate-rich hemicycle. F) A $40 \mathrm{kyr}$ periodic signal with background sedimentation rate of $1 \mathrm{~cm} / \mathrm{kyr}$ was generated. The sedimentation rate was modeled to vary between $1.5 \mathrm{~cm} / \mathrm{kyr}$ and $0.5 \mathrm{~cm} /$ kyr from one hemicycle to the next. 
UPPER BRIDGE CREEK LIMESTONE
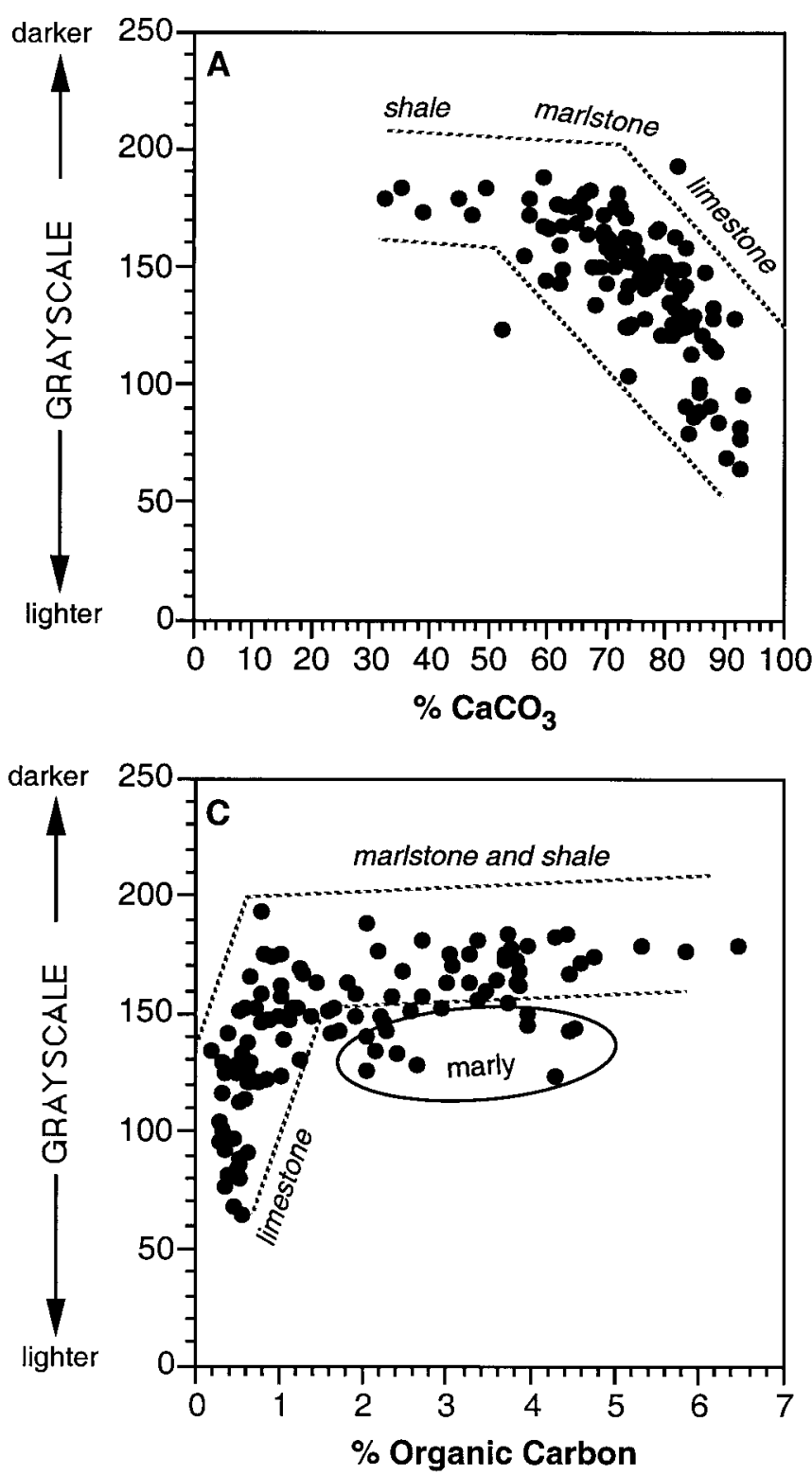

\section{LOWER BRIDGE CREEK LIMESTONE}
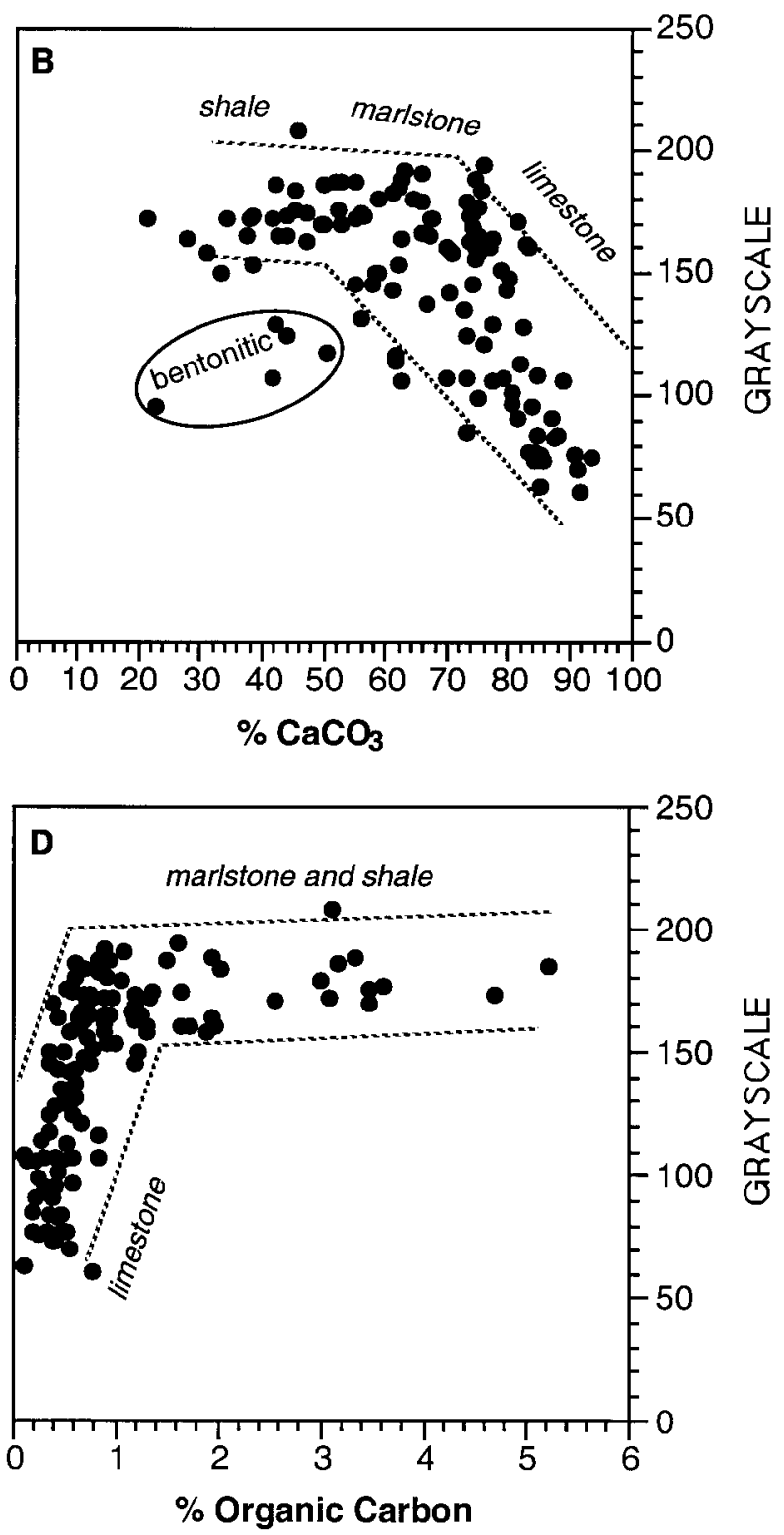

Fig. 4.-Crossplots of $\mathbf{A}$ ) grayscale value (from optical densitometry analysis) vs. $\% \mathrm{CaCO}_{3}$ for the upper Bridge Creek Limestone Member, B) grayscale value vs. \% $\mathrm{CaCO}_{3}$ for the lower Bridge Creek Limestone Member, C) grayscale value vs. \% TOC for the upper Bridge Creek Limestone Member, and D) grayscale value vs. \% TOC for the lower Bridge Creek Limestone Member. All data from the \#1 Portland core (see Fig. 1).

FIG. 5.-EHA time-frequency plot of the stratigraphic model. The model input consists of a calculated orbitally forced insolation time series sampled every 1 kyr, converted to stratigraphy using a sedimentation rate function. The rate is modified to emulate sedimentation effects as shown in the left panel. This modified time series was analyzed with EHA to produce a colored plot in which the $y$ axis represents height above base of the synthetic stratigraphic section, the $x$ axis represents frequency, and the $z$ axis (color scale) represents amplitude. Sedimentation effects are indicated in the colored plot by drift, rapid shift and smearing, and bifurcation of dominant amplitude peaks through time (see explanation in text).

FIG. 6.-EHA time-frequency plot of the high-resolution optical densitometry data set (Bridge Creek Limestone Member, U.S.G.S. \#1 Portland core). The optical densitometry stratigraphic data series is plotted versus height above base of the study interval at left. The EHA plot displays height above base as the $y$ axis, frequency as the $x$ axis, and amplitude (see color scale) as the $z$ axis. The power spectrum located at the top of the EHA plot was calculated for the entire optical densitometry data set, using MTM spectral analysis with five $3 \pi$ tapers. The significance of the results are evaluated by harmonic F-tests. Components that exceed the $95 \%$ significance level are denoted (using an average sedimentation rate for the study interval of $0.92 \mathrm{~cm} / \mathrm{kyr}$ ). 


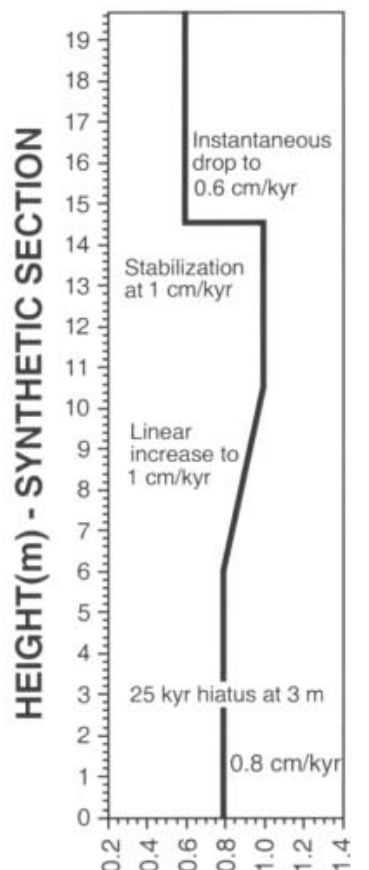

Modeled Sedimentation Rate $(\mathrm{cm} / \mathrm{kyr})$

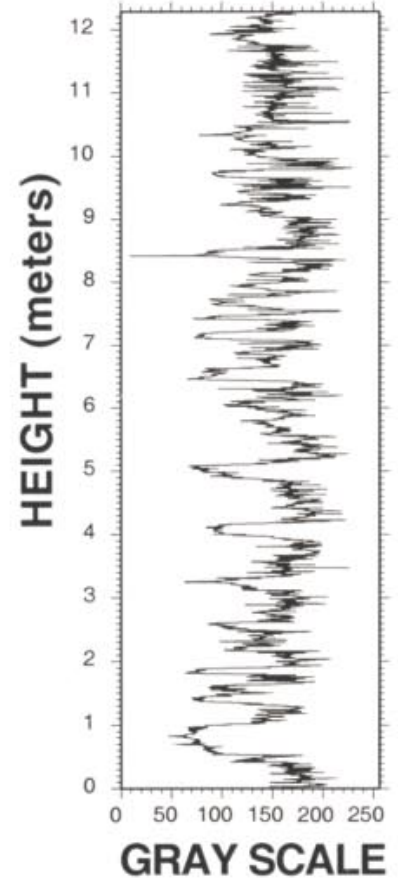

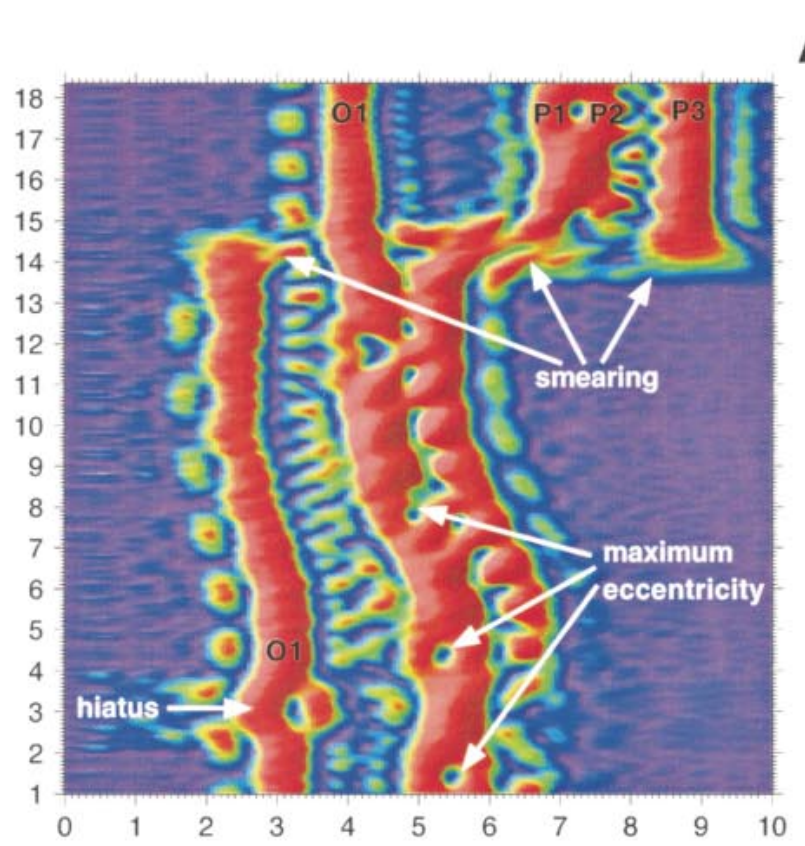

AMPLITUDE

FREQUENCY (cycles/meter)

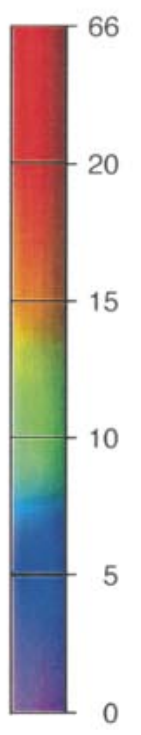

EHA OBSERVATIONS
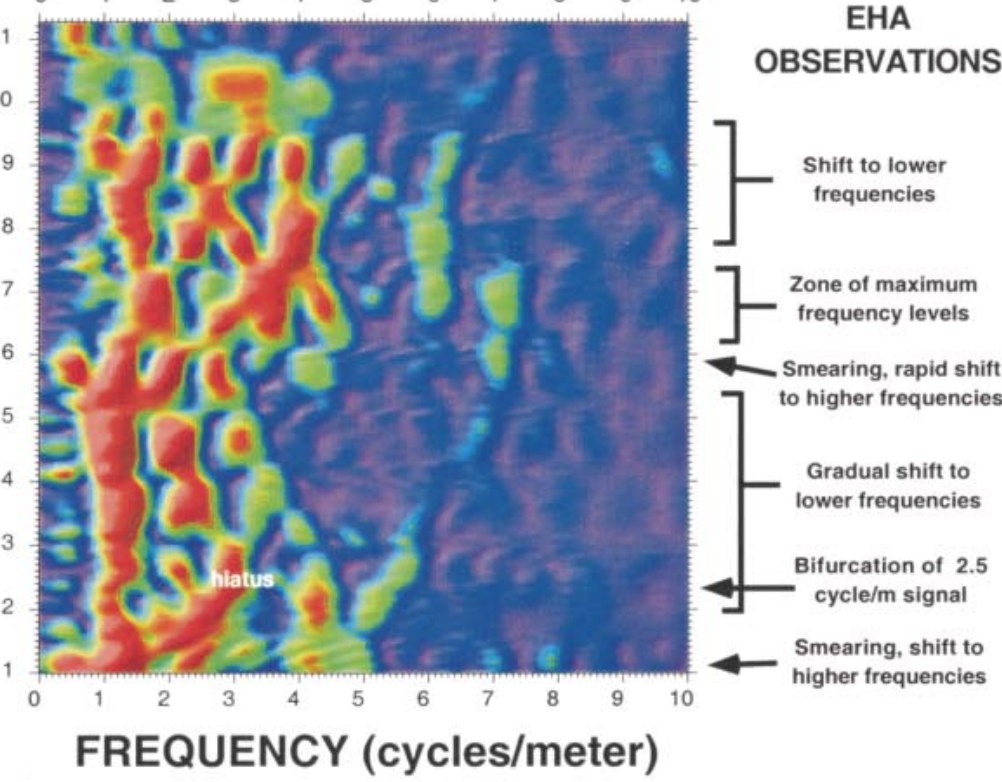

AMPLITUDE 
TABLE 2.-Assessment of periodicities in the Bridge Creek Limestone (see also Fig. 7).

\begin{tabular}{|c|c|c|c|c|c|c|}
\hline $\begin{array}{l}\text { Spatial Frequency } \\
\text { (cycles/m) }\end{array}$ & Significance & $\begin{array}{l}\text { Periodicities Using } \\
\text { Dated Bentonites }\end{array}$ & $\begin{array}{l}\text { After Adjusting } \\
78 \text { to } 95 \mathrm{kyr}\end{array}$ & $\begin{array}{c}\text { Predicted } \\
\text { Cretaceous Periodicities }\end{array}$ & $\begin{array}{l}\text { \% Difference from } \\
\text { Predicted Value }\end{array}$ & $\begin{array}{c}\text { Milankovitch } \\
\text { Orbital Interpretation }\end{array}$ \\
\hline 1.028571 & $99.89 \%$ & $78.41 \mathrm{kyr}$ & $94.78 \mathrm{kyr}$ & $94.78 \mathrm{kyr}$ & $0 \%$ & Eccentricity (E1) \\
\hline 2.628571 & $89.72 \%$ & $30.68 \mathrm{kyr}$ & $37.09 \mathrm{kyr}$ & $38.94 \mathrm{kyr}$ & $-4.75 \%$ & Obliquity (O1) \\
\hline 4.228571 & $97.00 \%$ & $19.07 \mathrm{kyr}$ & $23.06 \mathrm{kyr}$ & $22.34 \mathrm{kyr}$ & $+3.20 \%$ & Precession (P1) \\
\hline 5.314286 & $93.11 \%$ & $15.18 \mathrm{kyr}$ & $18.34 \mathrm{kyr}$ & $18.54 \mathrm{kyr}$ & $-1.05 \%$ & Precession (P2) \\
\hline 8.457143 & $91.62 \%$ & $9.54 \mathrm{kyr}$ & $11.53 \mathrm{kyr}$ & - & - & Harmonic of P1 \\
\hline
\end{tabular}

them can be clearly resolved. When the eccentricity is low, there is not enough precessional variance for the method to resolve the $23.7 \mathrm{kyr}$ and the 22.38 kyr periodicities separately. This effect does not occur in the case of the 41.03 kyr obliquity signal. Therefore, when sedimentation rates are on the order of $1 \mathrm{~cm} / \mathrm{kyr}$, and 2 meter windows are used (i.e., $200 \mathrm{kyr}$ windows) in the EHA, the obliquity signal is the preferred component for revealing discontinuities in the sedimentation record.

The linear increase in sedimentation rate from 6 to 10.5 meters is expressed as a gradual shift of the orbital components to lower spatial frequencies, with little complication of the spectrum. The rapid decrease in sedimentation rate at 14.5 meters is apparent as a discontinuity in the EHA plot and is accompanied by smearing of the frequencies. Note that the precessional components are most clearly resolved at low sedimentation rates, because slower accumulation results in more time within the 2-meter window, and higher-frequency resolution is available at higher frequencies.

\section{APPLICATION OF EHA TO BRIDGE CREEK LIMESTONE}

Results from evolutive harmonic analysis of the Bridge Creek Limestone in the U.S.G.S. \#1 Portland core are shown in Figure 6. The high-resolution optical densitometry (grayscale) data were analyzed using three $2 \pi$ tapers and a $2 \mathrm{~m}$ moving window (incremented by $0.05 \mathrm{~m}$ ). Identification of the dominant frequencies in the EHA plot is facilitated by comparison with the MTM power spectral result for the entire grayscale data set (top, Fig. 6). Using MTM power spectral analysis with five $3 \pi$ tapers (to maximize the trade-off between resolution and statistical stability associated with the larger data window), the significant temporal periodicities were identified by calibrating the dominant peak to $95 \mathrm{kyr}$ (which assumes an average sedimentation rate of $0.92 \mathrm{~cm} / \mathrm{kyr}$ ). The paired signals for eccentricity (119 and $95 \mathrm{kyr}$ ) and obliquity (56 and $42 \mathrm{kyr}$ ) suggest the predominance of two major sedimentation regimes in the lower and upper parts of the study interval. The peaks at 14,16 , and $19 \mathrm{kyr}$ suggest nonstationary precessional components, and the $11 \mathrm{kyr}$ periodicity most likely reflects a harmonic due to the changes in bulk accumulation. The power spectral plot provides an indication of the location and amplitude expected in the EHA plot for signals corresponding to eccentricity, obliquity, and precession.

The model in Figure 5 serves as a guide to interpreting observations of the Bridge Creek EHA plot in Figure 6. For example, the prominent smearing across frequencies at the base of the time-frequency plot and at 6 meters is consistent with the rapid sedimentation rate decreases modeled in Figure 5. The first five meters of the study interval reveals a gradual shift of the dominant components to lower frequencies, suggesting an increase in bulk sedimentation rates (Fig. 6). A bifurcation of the frequency at about 2.5 cycles $/ \mathrm{m}$, near 2.9 meters above the base of the study interval (Fig. 6), suggests the presence of a hiatus. Complication of the spectrum across all Milankovitch-band frequencies, with a shift to higher frequency values at 6 meters, suggests a significant decrease in sedimentation (condensed zone). Finally, a pulse of increased sedimentation near 8 meters is reflected in another shift to lower frequencies (Fig. 6).

High-resolution bulk sedimentation rates for the Bridge Creek Limestone are reconstructed by tracking the highest frequency component that is: (1) persistent, (2) not severely affected by hiatus, and (3) statistically significant. The optimum tracking frequency is dependent upon window size and sedimentation rates, because these parameters dictate the degree to which any frequency can be estimated. The selected tracking component is then used to back-calculate changes in bulk sedimentation rate. This approach assumes that the frequency component is orbital in origin and is consistent over the sampled time series, and that perturbations in its spatial frequency reflect changes in bulk sedimentation. Park and Herbert (1987) applied a similar methodology to the Albian Piobbico core, in which they tracked the spatial frequency modulation of the dominant harmonic in $\% \mathrm{CaCO}_{3}$ and densitometer data series (assuming a monochromatic signal) and then used this modulation to tune the individual series. In our analysis, the component that occurs at approximately $1 \mathrm{cycle} / \mathrm{m}$ in the lower Bridge Creek Limestone, and the component between 1.5 and 2 cycles $/ \mathrm{m}$ in the upper Bridge Creek Limestone satisfy the criteria outlined above (1-3), and were used to reconstruct sedimentation rates.

The frequency modulation of the selected component is converted to a bulk sedimentation rate curve by assigning a constant temporal periodicity to it. The assignment of the appropriate orbital frequency was determined by using radiometrically dated bentonites in the study interval to establish estimates of an initial time scale, and then fine-tuning the spectra until characteristic orbital frequencies were achieved (within the constraints imposed by the radiometric dates). Obradovich (1993) has determined radiometric dates for 4 bentonites in the study interval using the ${ }^{40} \mathrm{Ar}-{ }^{39} \mathrm{Ar}$ method (Table 1).

The average dates of bentonites $\mathrm{A}$ and $\mathrm{B}$ yield a sedimentation rate of $1.24 \mathrm{~cm} / \mathrm{kyr}$ for the interval from 1.62 meters to 3.36 meters. Applying this value to convert the spatial frequency record at 2.15 meters (spanning optical densitometry data from 1.15 to 3.15 meters) to a temporal frequency record yields the periods expressed in Table 2 and Figure 7. This record was selected because most of the spatial window (1.47 meters of a 2 meter window) lies within the dated interval, yet the MTM harmonic analysis is not severely affected by the hiatus identified at 2.9 meters.

During the Cretaceous, the periods associated with the Earth's eccentricity are believed to have been similar to those of the Quaternary (94.782 kyr, 123.818 kyr, 404.178 kyr) (Berger and Loutre 1991; Berger et al. 1992). Deviation of these periodicities from their Quaternary values is believed to be negligible (less than or equal to $1.5 \%$ ) over the past $200 \mathrm{Ma}$ (Berger et al. 1992). However, the orbital periodicities associated with the Earth's obliquity and precession changed in association with evolution of the length of day and its effect on the precessional constant, and evolution of the main frequencies of the planetary system. Theoretical calculations for the Middle Cretaceous suggest a dominant obliquity period of 38.94 kyr, with a relatively minor obliquity component at $50.44 \mathrm{kyr}$, and dominant precessional periods of $22.34 \mathrm{kyr}$ and $18.54 \mathrm{kyr}$ (Berger et al. 1992). The fact that the periods calculated using the bentonite dates are not identical to these values is understandable, considering that the error estimates of the radiometrically dated bentonites are quite large relative to the periodicities (Table 1). If we adjust the $78 \mathrm{kyr}$ periodicity to $94.782 \mathrm{kyr}$ (the most dominant eccentricity term for the Quaternary following $404.178 \mathrm{kyr}$ ), we obtain periodicities to within $4.75 \%$ of the predicted precessional and obliquity orbital periods. The decrease in period discrepancy (Table 2) with increasing frequency is partially attributable to the Fourier method, which has higher resolution at higher frequencies. The $11.53 \mathrm{kyr}$ periodicity is not predicted by orbital theory, but it is a harmonic of P1 (23.06 kyr/2), suggesting differential compaction and/or differential accumulation on the 


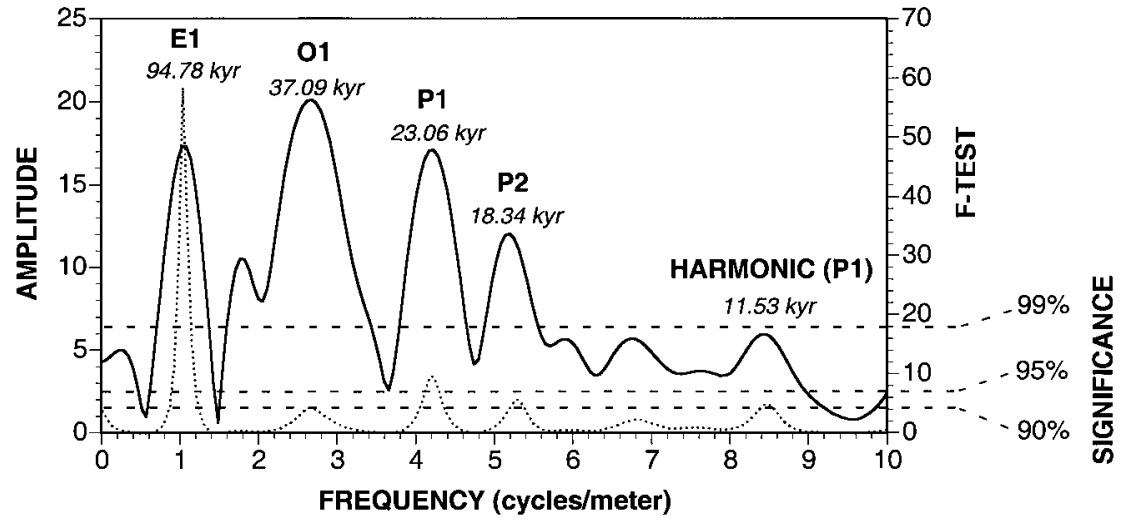

FIG. 7.- Harmonic analysis results from a 2meter window centered 2.15 meters above the base of the study interval. This record illustrates how the tracking frequency is used in the derivation of sedimentation rates. The bold line indicates amplitude, the dotted line indicates $F$ test result, and the dashed lines indicate $90 \%$, 95\%, and 99\% significance levels for the $F$-tests. The periodicities identified are discussed in the text and Table 2. couplet scale (see models in Figure 3E, 3F). Finally, based on our analysis of relative amplitude differences in the bifurcated obliquity signal (O1) at approximately 2.9 meters (Fig. 6) we determine that the depositional break has a minimum duration of $16 \mathrm{kyr}$.

Figure 8 shows the record of change in the spatial tracking frequency through time (frequency modulation), the effective sedimentation rates derived from them, and a plot of average time vs. depth for the study interval. From the results in Figures 6 and 8, the major features of Bridge Creek sedimentation include: (1) evidence of a rapid sedimentation rate decrease ("smearing") at the base of the lower Bridge Creek Limestone (transition from the underlying $M$. mosbyense biozone of the Hartland Shale into the $S$. gracile biozone), (2) a hiatus within the $N$. juddii biozone of the lower Bridge Creek Limestone, (3) a secular change in sedimentation rate within the study interval, with the lower Bridge Creek Limestone characterized by higher average bulk sedimentation rates (steeper slope on time-depth curve) than the upper Bridge Creek, (4) a rapid decrease in sedimentation rate beginning in the $P$. flexosum biozone, which represents a condensed interval separating the lower and upper parts of the member, and (5) four regularly occurring pulses in bulk sediment accumulation through the study interval (Fig. 8).

\section{DISCUSSION}

Evolutive harmonic analysis of a high-resolution optical densitometry record from the Bridge Creek Limestone (U.S.G.S. \#1 Portland core) reveals statistically significant periodic components throughout the study interval that are consistent with predicted Mid-Cretaceous precession, obliquity, and eccentricity frequencies. By tracking the highly significant eccentricity component (95 kyr) we are able to calculate high-resolution sedimentation rates through the study interval. This result realizes the full potential of cyclostratigraphic analysis as originally envisioned by Gilbert (1895): accurate reconstruction of relationships between rock and time in the geologic record. The implications of this result for paleoenvironmental analysis are extremely significant. In particular, the calculation of highresolution accumulation rates for proxies representing detrital, biogenic, and authigenic processes represents a quantum leap in interpretive power for strata of this age.

The integrated quantitative stratigraphic methodology developed herein depends on identification of effective proxies for the major sedimentary inputs to a deposit and placement of those proxies in a high-resolution time-rock framework. Hemipelagic depositional systems are characterized by three primary sediment inputs (terrigenous, volcanigenic, and pelagic) reflected by the most abundant sedimentary components (clay, carbonate, and organic matter); these may be augmented by authigenic components, such as major or minor elements and trace metals, that can serve as sensitive indicators of chemical conditions in the water column and pore waters during deposition and early diagenesis (e.g., Arthur et al. 1985; Arthur and Dean 1991; Brumsack 1986; Arthur and Sageman 1994; Jones and Manning 1994; Dean and Arthur 1998). In hemipelagic strata deposited in distal settings, such as the Bridge Creek Limestone, measured \% TOC values dominantly reflect a history of pelagic biogenic flux (the terrigenous organic contribution is $<10 \%$ of preserved $\mathrm{C}_{\text {org }}$; Pratt 1984) due to marine phytoplanktonic production; dilution of this organic matter by siliciclastic, volcanigenic, and/or skeletal carbonate inputs; and loss of carbon through remineralization by bacterial decomposition and/or heterotrophic reworking (preservation). Under conditions of relatively slow bulk sedimentation, decomposition rates scale to depositional redox conditions such that maximum preservation correlates with maximum euxinicity (Canfield 1994). Thus, when accumulation rates can be calculated for detrital and/or volcanigenic elements, products of biogenic production, and authigenic elements sensitive to redox conditions in the depositional environment, the possibility exists to deconvolve the relative roles of the major depositional processes (italicized above).

To develop an appropriate data base for analysis of the Bridge Creek Limestone we combined data from previous analyses of $\% \mathrm{CaCO}_{3}$ and $\%$ TOC in the Portland core (Sageman et al. 1997; Sageman et al. 1998) with more recent geochemical results from the same samples (i.e., bulk concentrations of \% Ti, $\mathrm{Al}, \mathrm{Na}, \mathrm{K}, \mathrm{Fe}, \mathrm{Mg}$, and ppm Mo by ICP-spectroscopy). The relative abundances of selected components were transformed into accumulation rates using the high-resolution sedimentation rate curve and an average bulk density value for hemipelagic sediment of $2.6 \mathrm{~g} / \mathrm{cm}^{3}$ (Bralower and Thierstein 1987). We calculated 2-meter moving-window averages for the concentration data prior to conversion to accumulation. This approach is appropriate because the high-resolution sedimentation rates are themselves based on a 2-meter moving window (representing an average over approximately 200-400 kyr of depositional time).

In the discussion below we first outline the geologic data that support our EHA-based reconstruction of sedimentation rates in the Bridge Creek Limestone. We then use the sedimentation-rate curve to calculate accumulation rates for selected geochemical parameters, chosen to reflect detrital inputs (Ti), pelagic biogenic inputs $\left(\mathrm{CaCO}_{3}, \mathrm{TOC}\right)$, and depositional redox conditions (Mo) through the study interval (Fig. 9). We conclude with a new interpretation of the history of Bridge Creek sedimentation that significantly improves understanding of the nature of OAE II in the Western Interior basin.

\section{Evidence Supporting the EHA Sedimentation-Rate Curve}

Numerous features of the Greenhorn Formation and its lateral equivalents provide supporting evidence for our major conclusions concerning Bridge Creek sedimentation. For example, the abrupt decrease in sedimentation suggested by EHA smearing at the base of the study interval (Fig. 6) corresponds to the contact of the Hartland Shale and the Bridge Creek Limestone. At this contact, deposition in the central basin shifted from 


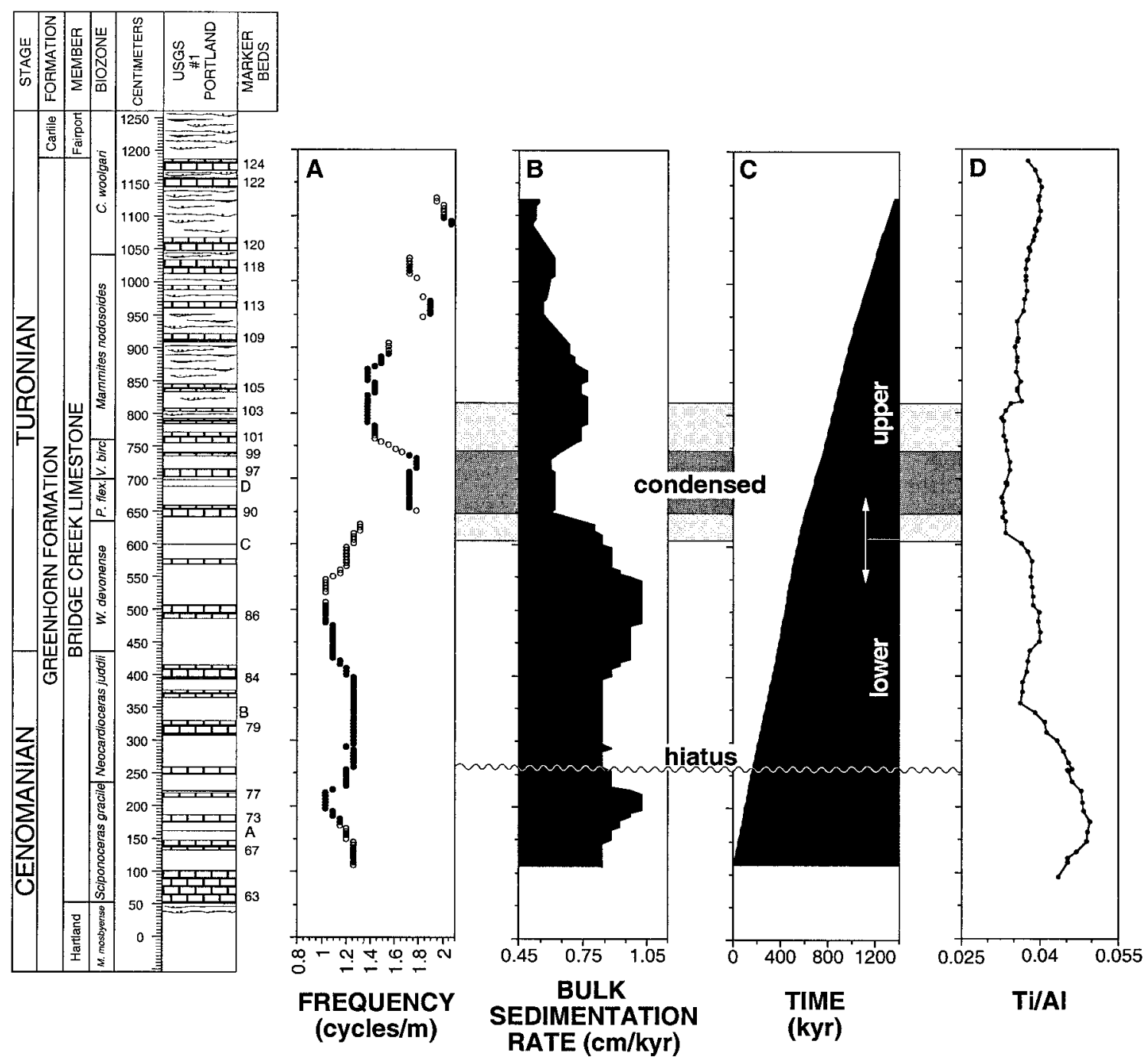

FIG. 8.-Derivation of bulk sedimentation rates for the Bridge Creek Limestone Member, \#1 Portland core. Lithology is plotted against: A) the tracking frequency isolated from EHA results; filled circles indicate frequencies with significance levels $\geq 90 \%$, and empty circles indicate frequencies with significance levels less than $90 \%$ but $\geq 80 \%$; B) effective bulk sedimentation rates calculated by assigning a constant periodicity of $94.782 \mathrm{kyr}$ to the variable spatial frequency; C) the temporal-spatial mapping function for the succession determined by integration of the bulk sedimentation rate curve in part B; D) A 2-meter moving average of Ti/Al values shown for comparison to the bulk sedimentation rate. Also shown are the location of the hiatus at $2.6 \mathrm{~m}$, the division between lower and upper member subdivisions relative to the inflection in the time-rock relationship (panel C), and the position of the condensed zone based on EHA derived sedimentation rates (dark stipple) and the minimum in Ti/Al ratio (light stipple).

dominance of calcareous shale to limestone interbedded with marlstone or calcareous shale, with a concomitant increase in average carbonate content as a percentage of bulk sediment. This transition has been correlated westward to a $170 \mathrm{~km}$ transgressive backstep of the shoreline within the Dakota Sandstone of southwestern Utah (Elder et al. 1994). If Obradovich's (1993) radiometric dates are used to interpolate boundary ages for the members of the Greenhorn Formation (Kauffman et al. 1993), the resulting longterm average for effective sedimentation rate $\left(S_{\mathrm{e}}\right)$ in the Hartland Shale is about $2.7 \mathrm{~cm} / \mathrm{kyr}$ (more than twice the lower Bridge Creek EHA-based estimate). Thus, average sedimentation rates based on the radiometric time scale, as well as geological context, support the EHA result.

The hiatus identified by EHA in the U.S.G.S. \#1 Portland core ( $N$. juddii biozone) is not readily apparent in core or outcrop within the central basin region. However, sedimentary discontinuity surfaces have been described from this stratigraphic interval in Bridge Creek Limestone sections from southwestern New Mexico (Hook and Cobban 1981). These surfaces are characterized by nodular to calcarenitic limestones that show evidence of erosion, reworking, and phosphatization. In a previous study, Elder (1985) reported that the top of the LS-5 limestone bed in his measured section was conspicuously calcarenitic (see bed at about 2.75 meters in Figure 2; the same feature appears at $2.58 \mathrm{~m}$ in Figures 8 and 9 after removal of Bentonite A for EHA). Calcarenite (or skeletal limestone) beds in the Greenhorn Limestone have been interpreted by previous workers (e.g., Kauffman 1977; Hattin 1986; Sageman 1996) to reflect winnowing and condensation, but there has never been a case in which the extent of timerock distortion associated with such features could be evaluated. Our results broadly quantify that distortion (minimum 16 kyr hiatus) and support the interpretation of siliciclastic starvation during limestone (and especially calcarenite) formation. In addition, this suggests that a starvation event associated with the end of LS-5 deposition was particularly pronounced, perhaps reflecting a rare confluence of declining pelagic carbonate production prior to increase in delivery of terrigenous sediment to the central basin.

The stratigraphic position of the abrupt decrease in sedimentation rate to minimum values for the study interval beginning in the $P$. flexosum 

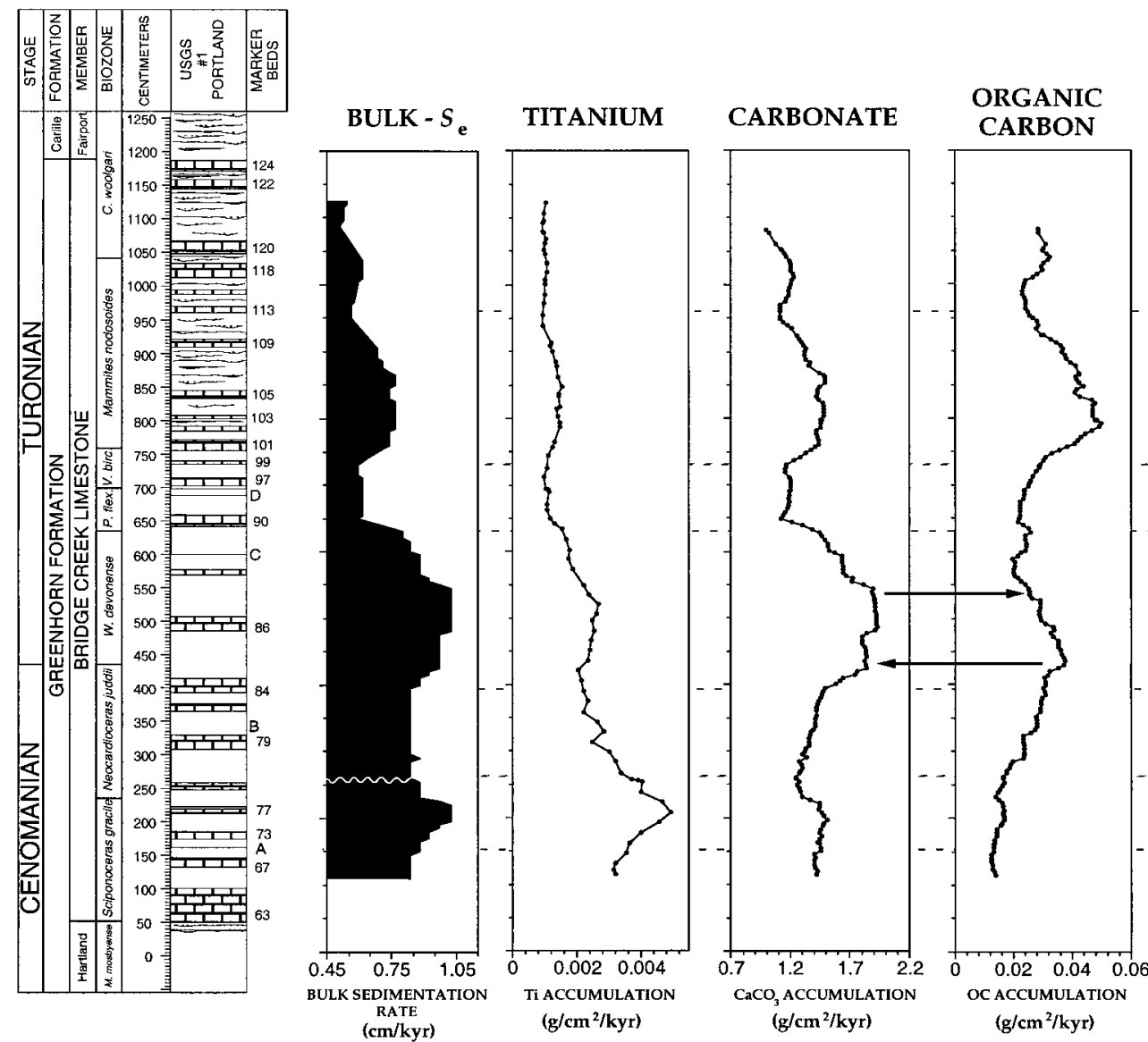

\section{MOLYBDENUM}

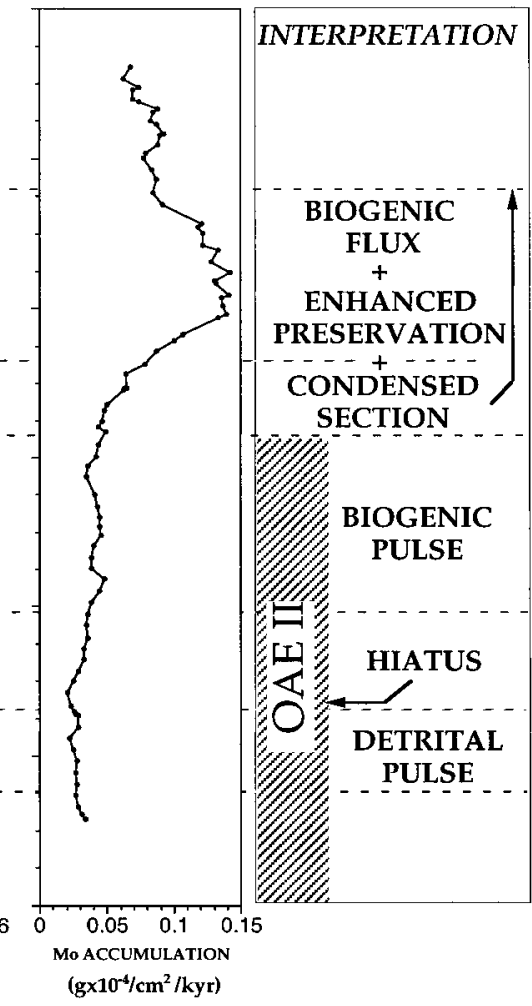

FIG. 9.-Accumulation rates of detrital (Ti), biogenic $\left(\mathrm{CaCO}_{3}, \mathrm{TOC}\right)$, and authigenic-redox sensitive (Mo) components are plotted against the bulk effective sedimentation rate and the stratigraphic section for U.S.G.S. \#1 Portland core. Values representing 2-meter moving-window averages of the raw geochemical data were used with the EHA-derived bulk sedimentation rates to calculate accumulation. Interpretations are summarized in right-hand column.

biozone (condensed interval, Figs. 8, 9) has been identified by numerous previous researchers as the peak highstand of the Greenhorn Cyclothem (Kauffman 1977, 1985; Kauffman and Caldwell 1993; Sageman et al. 1998). This conclusion is largely based on the distribution pattern of basinal lithofacies and the paleogeography of early Turonian shorelines, which suggest greatest water depths and maximum coastal onlap at this time (Kauffman 1984; Elder and Kirkland 1994; Sageman and Arthur 1994). Interestingly, enrichment in \% $\mathrm{TOC}$ and $\% \mathrm{CaCO}_{3}$, predicted by sequence stratigraphic theory to characterize basinal condensed sections (Loutit et al. 1988), does not coincide with the maximum decrease in bulk sedimentation but appears to lag after it (Figs. 2, 9).

The high-resolution sedimentation rates identified in the upper Bridge Creek Limestone are consistent with the average estimate $(0.6 \mathrm{~cm} / \mathrm{kyr})$ used by Sageman et al. (1997) and Sageman et al. (1998) in their initial spectral analyses of the study interval. In addition, an estimate of the duration of the entire study interval based on the EHA methodology is reasonably consistent with the duration derived from interpolation using Obradovich's (1993) radiometric time scale (1.4 Myr vs. 1.8 Myr, respectively). The difference in estimates of duration reflects the exclusion of the lower and upper 1 meter of the study interval and the loss of time associated with hiatus (Fig. 8) that characterize the EHA method.

As a final independent test of the EHA derived sedimentation rate curve we used the ratio Ti/Al (Fig. 8), which has been used as a proxy for changes in the grain size of fine-grained sediments (Bertrand et al. 1996) and ancient mudrocks (Arthur and Dean 1991; Murphy et al. 2000). In general, Ti represents a conservative tracer of detrital input reflecting subtle variations in delivery of the "greater than clay-size" fraction of weathered aluminosilicate source rocks. $\mathrm{Al}$ is a dominant cation in the clays that constitute mudrocks, occurring in similar proportions in both detrital and volcanigenic clay minerals. Plotting these elements as a concentration ratio avoids the problem of variable dilution by the more dominant component, $\mathrm{CaCO}_{3}$ (Dean and Arthur 1998). Bertrand et al. (1996) suggested that small changes in the Ti/Al ratio could be used to track changes in detrital input (positive correlation between detrital flux and Ti/Al), but Murray and Leinen (1996) noted that the relationship might be compromised in dominantly biogenic sediments where Al may be anomalously enriched via scavenging by organic particles as they settle through the water column. In contrast, our data show that increases in the accumulation rate of organic matter correspond to slightly higher $\mathrm{Ti} / \mathrm{Al}$ values rather than the opposite, which would be expected if scavenging played a significant role in $\mathrm{Al}$ accumulation (Figs. 8, 9). This may reflect reduced importance of the scavenging process when the depth of the water column is relatively shallow (maximum estimate $\leq 300 \mathrm{~m}$; Sageman and Arthur 1994).

The Ti/Al ratio tracks the changes in EHA-based sedimentation rates as follows (Fig. 8): overall decrease from the base to the condensed zone between 6 and $8 \mathrm{~m}$, two pulses of increase from 1 to $3 \mathrm{~m}$ and from 4 to $6 \mathrm{~m}$, the lowest values in both curves from 6 to $8 \mathrm{~m}$, and a slight increase in Ti/Al associated with increase in $S_{\mathrm{e}}$ at about $8 \mathrm{~m}$. From 9 to $12 \mathrm{~m}$ the $\mathrm{Ti} / \mathrm{Al}$ curve increases slightly whereas the sedimentation rate curve continues to decline with one minor pulse at about $10.3 \mathrm{~m}$. These observations suggest that there is a secular relationship between bulk sedimentation and 
detrital flux but that the relationship becomes attenuated as the relative proportion of biogenically produced constituents increases in the sediment.

\section{Integrated Quantitative Stratigraphy of the Bridge Creek Limestone}

The significance of the methodology outlined in this study lies in its potential to resolve the mechanisms that controlled hemipelagic sedimentation in the Western Interior basin. This is particularly significant in light of questions about the nature of OAE II in the seaway. Did sediments in the Western Interior basin simply record a shift in the global carbon reservoir reflecting increased burial of organic matter elsewhere but with no concomitant local environmental expression of the oceanic anoxic event? This conclusion is suggested by the low TOC content and burrowed character of strata within the OAE II interval, which is normally represented by TOC-rich, laminated black shales (Schlanger et al. 1987). However, some of the marlstone beds within the OAE II interval do show organic carbon enrichment (Fig. 2), and Arthur et al. (1998) proposed that these units reflect the actual environmental expression of OAE II in the Western Interior sea. In the Arthur et al. (1998) hypothesis, sea-level rise to a critical limit at the southern silled entrance of the basin is a key factor. During Hartland Shale deposition the basin was relatively restricted and more frequently stratified (by persistence of seasonal thermoclines?), explaining the more consistent enrichment in organic carbon (e.g., Sageman 1985; Sageman and Bina 1997). With the basal Bridge Creek transgressive pulse the basin became better circulated as well-mixed surface waters from the south increased their influence in the basin. Once eustatic rise reached a critical threshold, however, it became possible to advect $\mathrm{O}_{2}$-poor, nutrient-rich water into the seaway from a mid-water oxygen minimum zone (OMZ) that intersected the northern margin of Tethys near the southern silled entrance of the seaway. Advection of these waters into the seaway may have been the consequence of an estuarine-type circulation pattern that is hypothesized to have exported surface water from the basin, causing import of deeper water masses from the Boreal and Tethys seas (Slingerland et al. 1996). According to Arthur et al. (1998) this advection event caused either a pulse in marine algal productivity or an increase in preservation potential due to lower oxygen levels, or both, and it left a record of enhanced TOC in the upper part of the OAE II interval. If this hypothesis is correct, the Western Interior sedimentary record suggests that OAE II influenced the global carbon reservoir contemporaneously, but the environmental expression of the event was significantly diachronous.

The record of changes in accumulation rates for detrital, biogenic, and redox related proxies should provide a clear test of the Arthur et al. (1998) hypothesis and a comprehensive reconstruction of Bridge Creek hemipelagic sedimentation. Analysis of trends in data that include the underlying Hartland Shale suggests that a significant decrease in siliciclastic sediment delivery rather than an increase in carbonate production initiated the shift to carbonate-rich Bridge Creek facies (Fig. 10). Bulk effective sedimentation rate decreased from an average value of $2.7 \mathrm{~cm} / \mathrm{kyr}$ in the Hartland Shale to less than $1 \mathrm{~cm} / \mathrm{kyr}$ in the Bridge Creek Limestone. Using the Hartland Shale bentonite-based estimate for $S_{\mathrm{e}}$ to calculate accumulation rates allows a general comparison of processes. For example, although both carbonate and detrital components show decreases in accumulation across the transition, the change in accumulation rate for the detrital components $\mathrm{Si}, \mathrm{Al}$, and $\mathrm{Ti}$ ranges from 78 to 85 to $500 \%$, respectively, whereas the change in $\mathrm{CaCO}_{3}$ accumulation is only about $36 \%$. This evidence, which supports a secular change in detrital dilution rather than increase in carbonate production, is consistent with the conclusions of Pratt (1984) based on changes in discrete illite and clay-size quartz.

Following this initial transition at the beginning of OAE II, there are four pulses in bulk sedimentation to account for. The first pulse at about $2 \mathrm{~m}$ (Figs. 8, 9) corresponds to maximum values in Ti accumulation with only slight increase in $\mathrm{CaCO}_{3}$ and TOC accumulation rates, suggesting an increase in detrital delivery. This appears odd in light of the interpreted secular decrease in detrital supply across the underlying transition from Hartland to Bridge Creek facies discussed above. Average Ti/Al ratios are almost identical between the two members of the Greenhorn Formation ( 0.039 vs. 0.037 ), indicating that the proportionality between $\mathrm{Ti}$ and $\mathrm{Al}$ did not change significantly even though the average relative abundance of $\mathrm{Ti}$ decreased by almost $50 \%$ ( $0.186 \%$ vs. $0.097 \%$, respectively). Yet, the interval around $2 \mathrm{~m}$ in Figures 8 and 9 is characterized by values of Ti accumulation and $\mathrm{Ti} / \mathrm{Al}$ ratio that are double the member averages.

In order to evaluate the possibility that the Ti/Al trend reflects some change in elemental proportions associated with volcaniclastic sediment (one of the thickest bentonites occurs in this zone) we considered trends in the ratios of $\mathrm{Na} / \mathrm{K}$ and $\mathrm{K} /(\mathrm{Fe}+\mathrm{Mg})$. Dean and Arthur (1998) showed that these ratios can help distinguish detrital from volcaniclastic contributions to the clay fraction of Cretaceous hemipelagic strata because $\mathrm{K}$ is most likely associated with river-born discrete illite, whereas $\mathrm{Na}$ and $\mathrm{Fe}+\mathrm{Mg}$ are most likely associated with the mixed-layer clays representing altered volcanic ash. Although there is a significant shift in average values of these ratios toward the volcaniclastic endmember across the HartlandBridge Creek transition (55\% increase in $\mathrm{Na} / \mathrm{K}, 38 \%$ decrease in $\mathrm{K} /$ $(\mathrm{Fe}+\mathrm{Mg})$ ), they do not support the interpretation of a volcaniclastic pulse at $2 \mathrm{~m}$. In fact, the trend in $\mathrm{K} /(\mathrm{Fe}+\mathrm{Mg})$ supports the interpretation of a detrital pulse. Furthermore, Dean and Arthur (1998) showed that pure bentonites have very high $\mathrm{Al} / \mathrm{Ti}$ ratios suggesting very low Ti content. We concur with the conclusion of Dean and Arthur (1998) that the volcaniclastic fraction is relatively minor in most of the samples analyzed and confirm that the decrease in bulk sedimentation rate at the Hartland-Bridge Creek transition reflects mainly the decrease in detrital dilution.

The explanation for the apparent detrital pulse at $2 \mathrm{~m}$ can be found in the stacking pattern of shoreface deposits in southwestern Utah: Elder et al. (1994) showed that, following the major transgression that initiated deposition of Bridge Creek facies, there is a progradational stacking of shoreface deposits that reaches its most basinward position in the upper part of the $S$. gracile biozone, precisely coincident with our apparent detrital pulse. Following the shift to lower overall detrital influence in the basin, and the increased proportion of carbonate as a fraction of bulk sediment, the impact of slightly coarser mineral grains (sphene, illmenite) in transported plumes of riverine material may have been significantly enhanced in this brief interval of time. The alternate interpretation would be a transient shift in provenance, but the correspondence of the $\mathrm{Ti} / \mathrm{Al}$ ratio with other data discussed herein argue against this interpretation.

The next pulse in bulk sedimentation corresponds to the upper, TOCrich part of the OAE II interval, which spans the boundary between $N$. juddi and $W$. devonense biozones (Fig. 9). This interval is characterized by a slight increase in $\mathrm{Ti}$ accumulation, but the major increase in bulk sedimentation is clearly attributable to increases in $\mathrm{CaCO}_{3}$ and TOC accumulation. This suggests a pulse of biogenic production and/or increased preservation. Interestingly, the entire lower half of the Bridge Creek Limestone, including this zone of TOC-enriched marlstones, is characterized by low rates of Mo accumulation (Fig. 9). This element, normally very rare in crustal rocks and seawater $(<1-3 \mathrm{ppm})$, becomes authigenically enriched in sediments deposited under sulfidic conditions and low sedimentation rates (Emerson and Huested 1991; Helz et al. 1996; Dean et al. 1999). Thus it provides an excellent indicator of benthic paleo-oxygen levels. Mo occurs in relative abundance in the underlying organic-rich Hartland Shale (average concentration $>20 \mathrm{ppm}$ ), but its concentration decreases significantly in the Bridge Creek Limestone. Although the low rates of Mo accumulation in organic-poor, burrowed to bioturbated beds of the $S$. gracile biozone, characterized also by the highest levels of fossil diversity and abundance in the Greenhorn Formation (Elder 1985), are consistent with an interpretation of increased benthic oxygenation, the lack of enhanced Mo in the high-TOC zone of OAE II, coincident with the CenomanianTuronian mass extinction boundary, is enigmatic. This evidence suggests that organic-matter accumulation associated with OAE II resulted from a 


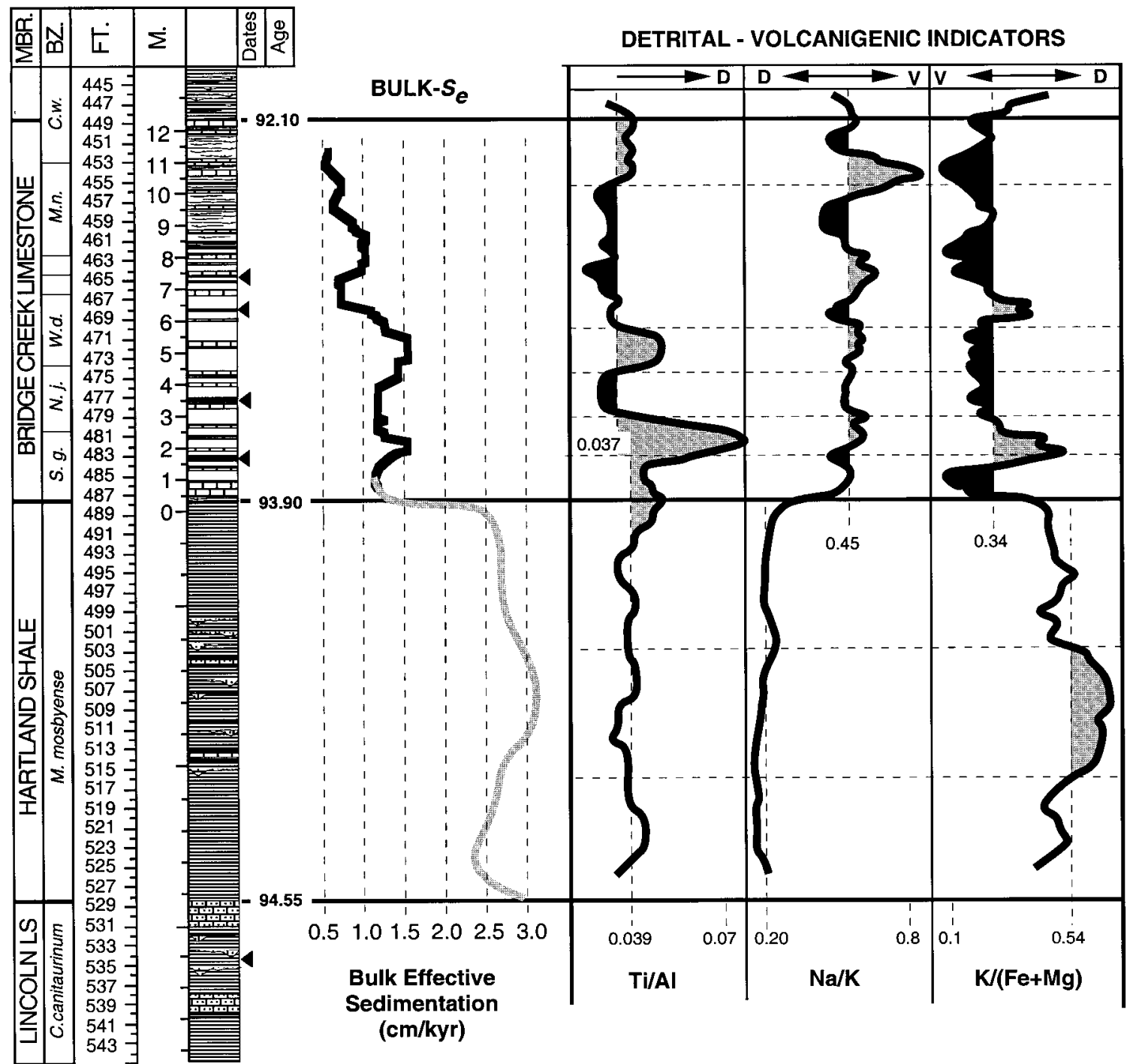

FIG. 10.-Summary of bulk effective sedimentation rates compared with detrital and volcanigenic indicators (elemental ratios) for the Hartland Shale and Bridge Creek Limestone Members in the \#1 Portland core. Stratigraphy is as in Figure 2 with locations of dated bentonites (Obradovich 1993) shown by black triangles, and the interpolated member boundary ages (Kauffman et al. 1993) based on them. The solid $S_{\mathrm{e}}$ curve is EHA derived; the gray $S_{\mathrm{e}}$ curve is based on the interpolated time scale and the $\mathrm{K} /(\mathrm{Fe}+\mathrm{Mg})$ curve. The member average for each elemental ratio is shown by dashed lines and the \pm deviations from average are shaded differentially. The trend toward "detrital" (D) or "volcanigenic" (V) is indicated for each ratio. These elemental ratios have been smoothed with an 8-point moving average.

major increase in phytoplanktonic production without a concomitant shift to anoxic or euxinic conditions in the Western Interior sea. An interesting feature of the record in Figure 9 is the difference in curve shape and accumulation rate maxima for $\mathrm{TOC}$ and $\mathrm{CaCO}_{3}$, possibly suggesting decoupling between the noncalcareous and calcareous phytoplankton.

Following the OAE II interval, the lowest values of $S_{\mathrm{e}}$ define the socalled condensed zone from about 6.5 to $7.5 \mathrm{~m}$, or the $V$. birchbyi and $P$. flexuosum biozones (Figs. 8, 9). This interval is characterized by minimum $\mathrm{Ti}$ accumulation, and $\mathrm{Ti} / \mathrm{Al}$ values that fall below the average for the Bridge Creek Limestone. As mentioned earlier, this narrow zone does not show increased levels of $\mathrm{CaCO}_{3}$, TOC, or Mo, as might be expected. At about $7.5 \mathrm{~m}$, at the top of the $V$. birchbyi biozone, accumulation rates of $\mathrm{CaCO}_{3}$, TOC, and Mo all rise, with TOC and Mo reaching peak values for the study interval between 8 and $9 \mathrm{~m}$ in the lower $M$. nodosoides biozone; the increase in accumulation rate of $\mathrm{CaCO}_{3}$ is subdued by comparison.

We interpret these observations as follows: judging from the character of the Ti accumulation curve (Fig. 9), the entire upper Bridge Creek Limestone could be viewed as a "condensed section." In fact, condensation appears to be increasing right into the upper few meters of the study interval, where skeletal limestone facies become common. The minimum in bulk $S_{\mathrm{e}}$ around $7 \mathrm{~m}$ represents the initiation of this condensed zone, which appears to have preceded the increases in biogenic production that produce the two pulses in bulk sedimentation at about 8 and $10 \mathrm{~m}$, respectively. In this case, however, the increases in accumulation of biogenic components are also associated with evidence for enhanced preservation (Mo concentrations in organic-rich beds vary from 10 to $20 \mathrm{ppm}$, similar to Hartland Shale values). Following the Arthur et al. (1987) hypothesis, the change in $\delta^{13} \mathrm{C}_{\text {org }}$ to pre-excursion levels in the Early Turonian suggests that burial of organic carbon had decreased on a global scale, perhaps because of lower levels of primary production and/or changes in preservation potential. However, the pulses in organic matter and Mo accumulation in the upper part of the Bridge Creek Limestone suggest that nutrient advection from some source was still influencing production and/or that a deeper water column may have more effectively prevented mixing of oxygen to bottom waters during winter storms. A further possibility is that once a threshold of condensation had been breached (in the condensed zone at $6.5 \mathrm{~m}$ ), the decom- 
position of organic matter under fluctuating redox conditions released nutrients that could be recycled to stimulate further production (see Murphy et al. 2000). Thus, organic-matter accumulation in the upper Bridge Creek may reflect the confluence of condensation, increased production, and enhanced preservation, resulting in maximum accumulation rates and the highest concentrations of TOC.

A final observation about these secular trends in detrital, biogenic, and authigenic accumulation concerns the timing of the major pulses discussed above. Although we have used the record of orbital forcing to derive sedimentation rates, we did not address the mechanisms of change in sedimentation on the scale of bedding couplets, and thus the proximate relationship between climate and sedimentation. Given the duration of the study interval, however, the four major pulses in bulk sedimentation could easily represent time intervals of approximately $400 \mathrm{kyr}$, the period of long eccentricity. If this is true it suggests that a fundamental underlying mechanism, such as the northern hemisphere hydrologic cycle, may link all the processes discussed above. Cycles of increased runoff to the basin would increase relative detrital influence in distal facies (1st pulse), would drive the circulatory advection of nutrient-rich waters into the basin according to the Slingerland et al. (1996) model and thus increase primary production (2nd pulse), and might also increase the flux of terrigenous nutrients to the seaway and enhance density stratification associated with development of seasonal thermoclines (2nd, 3rd, and 4th pulses).

\section{CONCLUSIONS}

In this study we pursued the philosophy that distortions in the preservation of orbital forcing in rhythmically bedded strata provide a high-resolution tool with which to assess the details of sedimentation history. Through the use of time-frequency analysis (EHA), and stratigraphic models to calibrate EHA to variations in sedimentation, we developed a quantitative method to reconstruct high-resolution sedimentation rates in rhythmically bedded sequences that preserve orbital forcing. This method allows not only estimation of sedimentation rates but also recognition of hiatuses in the section. Recognizing that the key to understanding hemipelagic sedimentation lies in constraining the relative roles of detrital, biogenic, and authigenic fluxes, we applied our derived bulk sedimentation rates to calculate the accumulation rates of proxies for these depositional processes. This integration of a quantitative chronostratigraphic technique with biogeochemical analysis represents a significant advance for studies of ancient hemipelagic strata. Application of the method to the Bridge Creek Limestone, Western Interior basin, allowed a test of major hypotheses concerning hemipelagic sedimentation, organic-carbon burial, and oceanic anoxic events. The most significant conclusions about the depositional history of the Bridge Creek Limestone resulting from this work include:

(1) Decreased detrital delivery to the central basin was the major control on the secular increase in $\% \mathrm{CaCO}_{3}$ associated with onset of Bridge Creek deposition. However, within the Bridge Creek Limestone biogenic pulses also played a role in the accumulation of $\mathrm{CaCO}_{3}$. A primary contribution of the integrated cyclostratigraphic analysis described herein is the quantification of relative roles for detrital dilution and productivity, the two processes previously identified as alternate mechanisms in the origin of Bridge Creek bedding cycles.

(2) Evidence for decoupling of peak carbonate production from peak organic flux during OAE II suggests a shift in dominance within the planktonic ecosystem, possibly reflecting variable nutrient preferences among calcareous and noncalcareous phytoplankton.

(3) The controls on accumulation of organic carbon varied over time. In the upper part of OAE II, enhanced production appears to have been the dominant factor. In the TOC-rich beds of the upper Bridge Creek Limestone, production and preservation were most likely linked, perhaps through nutrient regeneration from decaying organic matter under conditions of extreme starvation of siliciclastic sediment. These observations underscore the importance of constraining each of the three major factors associated with organic-matter enrichment in ancient strata.

(4) The record of Mo accumulation in the Bridge Creek Limestone indicates that at no time was OAE II associated with permanent anoxicity in the Western Interior seaway. Only later, when either nutrient levels were higher, water-column stratification persisted longer, and/or starvation of siliciclastic sediment exceeded a threshold for nutrient regeneration (probably all three) did anoxic or euxinic conditions exist for periods long enough to accumulate Mo and other redox-sensitive trace metals.

\section{ACKNOWLEDGMENTS}

The authors acknowledge the contribution of samples from the U.S.G.S. \#1 Portland core by Dean and Arthur (1998) and the U.S.G.S. Core Research Center, Denver Federal Center, as well as the generous financial support of Conoco Inc. through the DuPont Young Professor Award to Sageman. Josef Werne assisted with the acquisition of geochemical data in the early stages of the study. We also acknowledge stimulating discussions with M. Arthur, J. Laurin, and J. Rich, and thank M. Kominz, D. Osleger, J. Park, and J. Southard for helpful reviews and editorial comments on the manuscript.

\section{REFERENCES}

Arthur, M.A., And Dean, W.E., 1991, An holistic geochemical approach to cyclomania: Examples from Cretaceous pelagic limestone sequences, in Einsele, G., Ricken, W., and Seilacher, A., eds., Cycles and Events in Stratigraphy: Berlin, Springer-Verlag, p. 126-166.

Arthur, M.A., Dean, W.E., Pollastro, R., Scholle, P.A., and Claypool, G.E., 1985, A comparative geochemical study of two transgressive pelagic limestone units, Cretaceous Western Interior basin, U.S., in Pratt, L.M., Kauffman, E.G., and Zelt, F.B., eds., Fine-Grained Deposits and Biofacies of the Cretaceous Western Interior Seaway: Evidence of Cyclic Sedimentary Processes: SEPM, Field Trip Guidebook No. 4, p. 16-27.

Arthur, M.A., Dean, W.E., And Pratt, L.M., 1988, Geochemical and climatic effects of increased marine organic carbon burial at the Cenomanian/Turonian boundary: Nature, v. 335, p. 714-717.

ARthuR, M.A. And Sageman, B.B., 1994, Marine black shales: A review of depositional mechanisms and environments of ancient deposits: Annual Review Earth and Planetary Sciences, v. 22 , p. $499-552$.

Arthur, M.A., Sageman, B.B., Dean, W.E., Slingerland, R.L., Kump, L.R., and White, T.S., 1998, Transgression, advection of oxygen-depleted water, and eutrophication of the MidCretaceous Western Interior Seaway of North America (abstract): Geological Society of America, Annual Meeting, Toronto, Oct. 26-29, 1998, Abstracts with Program, p. 396.

Arthur, M.A., Schlanger, S.O., And Jenkyns, H.C., 1987, The Cenomanian-Turonian Oceanic Anoxic Event II. Paleoceanographic controls on organic matter production and preservation, in Brooks, J. and Fleet, A., eds., Marine Petroleum Source Rocks: Geological Society of London, Special Publication 26, p. 401-420.

Barron, E.J., Arthur, M.A., and Kauffman, E.G., 1985, Cretaceous rhythmic bedding sequences: A plausible link between orbital variations and climate: Earth and Planetary Science Letters, v. 72 , p. $327-340$.

Berger, A., And Loutre, M., 1991, Insolation values for the climate of the last 10 million years: Quaternary Science Reviews, v. 10, p. 297-317.

Berger, A., Loutre, M.F., AND LASKAR, J., 1992, Stability of the astronomical frequencies over the Earth's history for paleoclimate studies: Science, v. 255, p. 560-566.

Bertrand, P., Shimmield, G., Martinez, P.,Grousset, F., Jorissen, F., Paterne, M., Pujol, C., Bouloubassi, I., Buat Menard, P., Peypouquet, J.P., Beaufort, L., Sicre, M.A., LallierVerges, E., Foster, J.M., AND Ternois, Y., 1996, The glacial ocean productivity hypothesis; the importance of regional, temporal, and spatial, studies: Marine Geology, v. 130, p. 1-9.

Birchfield, G., ANd GHIL, M., 1993, Climate evolution in the Pliocene and Pleistocene from marine-sediment records and simulations: Internal variability versus orbital forcing: Journal of Geophysical Research, v. 98, p. 10,385-10,399.

Bralower, T.J., AND ThiERStein, H.R., 1987, Organic-carbon and metal accumulation in Holocene and Mid-Cretaceous marine sediments: palaeoceanographic significance, in Brooks, J., and Fleet, A.J., eds., Marine Petroleum Source Rocks: Geological Society of London, Special Publication 26, p. 345-369.

BRUMSACK, H.J., 1986, Trace metal accumulation in black shales from the Cenomanian/Turonian boundary event, in Walliser, O.H., ed., Global Bio-Events; A Critical Approach: Berlin, Springer-Verlag, Lecture Notes in Earth Sciences, v. 8, p. 337-343.

CANFIELD, D.E., 1994, Factors influencing organic carbon preservation in marine sediments: Chemical Geology, v. 114, p. 315-329.

Cobban, W.A., 1985, Ammonite recored from Bridge Creek Member of Greenhorn Limestone at Pueblo Reservoir State Recreation Area, Colorado, in Pratt, L.M., Kauffman, E.G., and Zelt, F.B., eds., Fine-Grained Deposits and Biofacies of the Cretaceous Western Interior Seaway: Evidence of Cyclic Sedimentary Processes: SEPM, Field Trip Guidebook No. 4, p. $135-138$.

Cobban, W.A., 1993, Diversity and distribution of Late Cretaceous ammonites, Western Interior, U.S., in Caldwell, W.G.E., and Kauffman, E.G., eds., Evolution of the Western Interior Basin: Geological Association of Canada, Special Paper 39, p. 435-452.

Cobban, W.A., And ScotT, G.R., 1972, Stratigraphy and ammonite fauna of the Graneros Shale 
and Greenhorn Limestone near Pueblo, Colorado: U.S. Geological Survey, Professional Paper P-0645, p. 108.

Dean, W.E., and ARThur, M.A., 1998, Geochemical expression of cyclicity in Cretaceous pelagic limestone sequences: Niobrara Formation, Western Interior Seaway, in Dean, W.E., and Arthur, M.A., eds., Stratigraphy and Paleoenvironments of the Cretaceous Western Interior Seaway, U.S.A: SEPM, Concepts in Sedimentology and Paleontology, no. 6., p. 227-255.

Dean, W.E., Piper, D.Z., And Peterson, L., 1999, Molybdenum accumulation in Cariaco basin sediment over the past 24 k.y.: A record of water-column anoxia and climate: Geology, v. 27 , p. 507-510.

Eicher, D.L., And Diner, R., 1989, Origin of the Cretaceous Bridge Creek cycles in the Western Interior, United States: Palaeogeography, Palaeoclimatology, Palaeoecology, v. 74, p. 127 146.

EldeR, W.P., 1985, Biotic patterns across the Cenomanian-Turonian extinction boundary near Pueblo, Colorado, in Pratt, L.M., Kauffman, E.G., and Zelt, F.B., eds., Fine-Grained Deposits and Biofacies of the Cretaceous Western Interior Seaway: Evidence of Cyclic Sedimentary Processes: SEPM, Field Trip Guidebook No. 4, p. 157-169.

Elder, W.P., Gustason, E.R., and Sageman, B.B., 1994, Basinwide correlation of parasequences in the Greenhorn Cyclothem, Western Interior, U.S.: Geological Society of America, Bulletin, v. 106, p. 892-902.

Elder, W.P., AND KirkLand, J.I., 1994, Cretaceous paleogeography of the southern Western Interior region, in Caputo, M., Peterson, J., and Franczyk, K., eds., Mesozoic Systems of the Rocky Mountain Region: SEPM, Special Publication, p. 415-440.

Emerson, S.R., And Huested, S.S., 1991, Ocean anoxia and the concentration of molybdenum and vanadium in seawater: Marine Chemistry, v. 34, p. 177-196.

FISCHER, A.G., 1980, Gilbert-bedding rhythms and geochronology, in Yochelson, E.I., ed., The Scientific Ideas of G.K. Gilbert: Geological Society of America, Special Paper 183, p. 93 104.

Fischer, A.G., 1991, Orbital cyclicity in Mesozoic strata, in Einsele, G., Ricken, W., and Seilacher, A., eds., Cycles and Events in Stratigraphy: Berlin, Springer-Verlag, p. 48-62.

Fischer, A.G., Herbert, T., And Premoli-Silva, I., 1985, Carbonate bedding cycles in Cretaceous pelagic and hemipelagic sediments, in Pratt, L.M., Kauffman, E.G., and Zelt, F.B., eds., Fine-Grained Deposits and Biofacies of the Cretaceous Western Interior Seaway: Evidence of Cyclic Sedimentary Processes: SEPM, Field Trip Guidebook 4, p. 1-10.

Gale, A.S., 1995, Cyclostratigraphy and correlation of the Cenomanian Stage in western Europe, in House, M.R., and Gale, A.S., eds., Orbital Forcing Timescales and Cyclostratigraphy: Geological Society of London, Special Publication 85, p. 177-198.

GilberT, G.K., 1895, Sedimentary measurement of geologic time: Geology, v. 3, p. 121-127.

Hancock, J.M., and Kauffman, E.G., 1979, The great transgressions of the Late Cretaceous: Geological Society of London, Journal, v. 136, p. 175-186.

HATTIN, D.E., 1971, Widespread, synchronously deposited, burrow-mottled limestone beds in Greenhorn Limestone (Upper Cretaceous) of Kansas and central Colorado: American Association Petroleum Geologists, Bulletin, v. 55, p. 412-431.

Hatrin, D.E., 1986, Carbonate substrates of the Late Cretaceous Sea, central Great Plains and southern Rocky Mountains: Palaios, v. 1, p. 347-367.

Hayes, J.M., Popp, B.N., TakigiKu, R., And Johnson, M.W., 1989, An isotopic study of biogeochemical relationships between carbonates and organic carbon in the Greenhorn Formation: Geochimica et Cosmochimica Acta, v. 53, p. 2961-2972.

Helz, G.R., Miller, C.V., Charnock, J.M., Mosselmans, J.F.W., Pattrick, R.A.D., Garner, C.D., AND Vaughan, D.J., 1996, Mechanisms of molybdenum removal from the sea and its concentration in black shales: EXAFS evidence: Geochimica et Cosmochimica Acta, v. 60 , p. $3631-3642$

HERBERT, T.D., 1987, Eccentricity and precessional orbital periodicities in a Mid-Cretaceous deep-sea sequence: identification and application to quantitative paleoclimatology: [unpublished Ph.D. dissertation], Princeton University, Princeton, New Jersey, 302 p.

HerberT, T.D., 1994, Reading orbital signals distorted by sedimentation: models and examples, in de Boer, P.L., and Smith, D.G., eds., Orbital Forcing and Cyclic Sequences: Internationa Association of Sedimentologists, Special Publication 19, p. 483-507.

Herbert, T.D., AND Fischer, A.G., 1986, Milankovitch climatic origin of Mid-Cretaceous black shale rhythms in central Italy: Nature, v. 321, p. 739-743.

Hinnov, L.A., PARK, J., AND ERBA, E., 2000, Lower-Middle Jurassic rhythmites from the Lombard Basin, Italy: a record of orbitally forced carbonate cycles modulated by secular environmental changes in West Tethys, in Hall, R.L. and Smith, P.L., eds., Advances in Jurassic Research 2000, GeoResearch Forum, v. 6, Trans Tech Publications, Zurich, Switzerland, p. 427-436.

Hook, S.C., And CobBan, W.A., 1981, Late Greenhorn (Mid-Cretaceous) discontinuity surfaces, southwest New Mexico, New Mexico Bureau of Mines and Mineral Resources, Circular 180, p. 5-21.

HufFMAn, E.W.D., JR., 1977, Performance of a new carbon dioxide coulometer: Microchemistry Journal, v. 22, p. 567-573.

Jones, B., And Manning, D.A.C., 1994, Comparison of geochemical indices used for the interpretations of paleoredox conditions in ancient mudstones: Chemical Geology, vol. 111, p. 111-129.

KAUfFMAn, E.G., 1977, Geological and biological overview: Western Interior Cretaceous Basin: Mountain Geologist, v. 13, p. 75-99.

Kauffman, E.G., 1984, Paleobiogeography and evolutionary response dynamic in the Cretaceous Western Interior Seaway of North America, in Westermann, G.E.G., ed., JurassicCretaceous Biochronology and Paleogeography of North America: Geological Association of Canada, Special Paper 27, p. 273-306.

Kauffman, E.G., 1985, Cretaceous evolution of the Western Interior Basin of the United States, in Pratt, L.M., Kauffman, E.G., and Zelt, F.B., eds., Fine-Grained Deposits and Biofacies of the Cretaceous Western Interior Seaway: Evidence of Cyclic Sedimentary Processes: SEPM, Field Trip Guidebook 4, p. IV-XIII.

Kauffman, E.G., and Caldwell, W.G.E., 1993, The Western Interior basin in space and time, in Caldwell, W.G.E. and Kauffman, E.G., eds., Evolution of the Western Interior Basin Geological Association of Canada, Special Paper 39, p. 1-30.

Kauffman, E.G., Sageman, B.B., Kirkland, J.I., Elder, W.P., Harries, P.J., and Villamil, T. 1993, Molluscan biostratigraphy of the Cretaceous Western Interior Basin, North America, in Caldwell, W.G.E., and Kauffman, E.G., eds., Evolution of the Western Interior Basin: Geological Association of Canada Special Paper 39, p. 397-434.

Kennedy, W.J., and Cobban, W.A., 1991, Stratigraphy and interregional correlation of the Cenomanian-Turonian transition in the Western Interior of the United States near Pueblo, Colorado, a potential boundary stratotype for the base of the Turonian stage: Newsletters in Stratigraphy, v. 24 (1/2), p. 1-33.

LASKAR, J., 1990, The chaotic motion of the solar system: A numerical estimate of the chaotic zones: Icarus, v. 88, p. 266-291.

LeEs, J., AND PARK, J., 1995, Multiple-taper spectral analysis: a stand-alone C-subroutine: Computers \& Geosciences, v. 21, p. 199-236.

Lichte, F.E., Golightly, D.W., And Lamothe, P.J., 1987, Inductively coupled plasma-atomic emission spectrometry, in Baedecker, P.A., ed., Methods for Geochemical Analysis: U.S Geological Survey, Bulletin 1770, p. B1-B10.

Loutit, T.S., Hardenbol, J., Vail, P.R., and Baum, G.R., 1988, Condensed sections: the key to age determination and correlation of continental margin sequences, in Wilgus, C.K. Hastings, B.S., Ross, C.A., Posamentier, H., Van Wagoner, J., and Kendall, C.G.St.C., eds., Sea-Level Changes: An Integrated Approach: SEPM, Special Publication 42, p. 183-213.

Murphy, A.E., Sageman, B.B., Hollander, D.J., Lyons, T.W., And Brett, C.E., 2000, Black shale deposition and faunal overturn in the Devonian Appalachian basin: Clastic starvation, seasonal water-column mixing, and efficient biolimiting nutrient recycling: Paleoceanography, v. 15 , p. 280-291.

MuRRAY, R.W., AND LEINEN, M., 1996, Scavenged excess aluminum and its relationship to bulk titanium in biogenic sediment from the central Equatorial Pacific Ocean: Geochimica et Cosmochimica Acta, v. 60, p. 3869-3878.

Obradovich, J., 1993, A Cretaceous time scale, in Caldwell, W.G.E. and Kauffman, E.G., eds., Evolution of the Western Interior Basin: Geological Society of Canada, Special Paper 39, p. $379-396$.

Paillard, D., Labeyrie, L., And Yiou, P., 1996, Macintosh program performs time series analysis: EOS, Transactions, American Geophysical Union, v. 77, p. 379.

Park, J., And Herbert, T., 1987, Hunting for paleoclimatic periodicities in a geologic time series with an uncertain time scale: Journal of Geophysical Research, v. 92, p. 14,02714,040

Park, J., Lindberg, C.R., and Vernon, F.L., III, 1987, Multitaper spectral analysis of highfrequency seismograms: Journal of Geophysical Research, v. 92, p. 12,675-12,684.

PratT, L.M., 1984, Influence of paleoenvironmental factors on the preservation of organic matter in middle Cretaceous Greenhorn Formation near Pueblo, Colorado: American Association of Petroleum Geologists, Bulletin, v. 68, p. 1146-1159.

Pratt, L.M., 1985, Isotopic studies of organic matter and carbonate in rocks of the Greenhorn Marine Cycle, in Pratt, L.M., Kauffman, E.G., and Zelt, F.B., eds., Fine-Grained Deposits and Biofacies of the Cretaceous Western Interior Seaway: Evidence of Cyclic Sedimentary Processes: SEPM, Field Trip Guidebook No. 4, p. 38-48.

Pratt, L., Arthur, M., Dean, W., and Scholle, P., 1993, Paleoceanographic cycles and events during the late Cretaceous in the Western Interior Seaway of North America, in Caldwell, W.G.E., and Kauffman, E.G., eds., The Evolution of the Western Interior Basin: Geological Association of Canada, Special Paper 39, p. 333-353.

RiPEPE, M., AND FisCHER, A.G., 1991, Stratigraphic rhythms synthesized from orbital variations, in Franseen, E.K., Watney, W.L., Kendall, C.G.St.C., and Ross, W., eds., Sedimentary Modeling; Computer Simulations and Methods for Improved Parameter Definition: Kansas State Geological Survey, Bulletin 233, p. 335-344.

RickEN, W., 1994, Complex rhythmic sedimentation related to third-order sea-level variations: Upper Cretaceous, Western Interior Basin, U.S.A., in de Boer, P.L., and Smith, D.G., eds. Orbital Forcing and Cyclic Sequences: International Association Sedimentologists, Special Publication 19, p. 167-193.

RoberTs, L.N.R., And KiRschbaum, M.A., 1995, Paleogeography of the Late Cretaceous of the Western Interior of Middle North America_Coal Distribution and Sediment Accumulation: U.S. Geological Survey, Professional Paper 1561, 115 p.

Sageman, B.B., 1985, High-resolution stratigraphy and paleobiology of the Hartland Shale Member: Analysis of an oxygen-deficient epicontinental sea, in Pratt, L.M., Kauffman, E.G., and Zelt, F.B., eds., Fine-Grained Deposits and Biofacies of the Cretaceous Western Interior Seaway: Evidence of Cyclic Sedimentary Processes: SEPM, Field Trip Guidebook 4, p. $112-121$

Sageman, B.B., 1996, Lowstand tempestites: Depositional model for Cretaceous skeletal limestones, Western Interior, U.S.: Geology, v. 24, p. 888-892.

Sageman, B.B., AND ARTHUR, M.A., 1994, Early Turonian paleogeographic/paleobathymetric map, Western Interior, U.S., in Caputo, M., Peterson, J., and Franczyk, K., eds., Mesozoic Systems of the Rocky Mountain Region: SEPM, Special Publication, p. 457-470.

Sageman, B.B., AND Bina, C., 1997, Diversity and species abundance patterns in Late Cenomanian black shale biofacies: Western Interior, U.S.: Palaios, v. 12, p. 449-466.

Sageman, B.B., Rich, J., Arthur, M.A., Birchileld, G.E., and Dean, W.E., 1997, Evidence For Milankovitch periodicities in Cenomanian-Turonian lithologic and geochemical cycles, Western Interior U.S.: Journal of Sedimentary Research, v. 67, p. 286-301.

Sageman, B., Rich, J., Savrda, C.E., Bralower, T., Arthur, M.A., and Dean, W.E., 1998, Multiple Milankovitch cycles in the Bridge Creek Limestone (Cenomanian-Turonian), Western Interior basin, in Dean, W.E., and Arthur, M.A., eds., Stratigraphy and Paleoen- 
vironments of the Cretaceous Western Interior Seaway, U.S.A.: SEPM, Concepts in Sedimentology and Paleontology, no. 6, p. 153-171.

SAVRDA, C.E., 1998, Ichnology of the Bridge Creek Limestone: Evidence for temporal and spatial variations in paleo-oxygenation in the Western Interior Seaway, in Dean, W.E., and Arthur, M.A., eds., Stratigraphy and Paleoenvironments of the Cretaceous Western Interior Seaway, U.S.A., SEPM, Concepts in Sedimentology and Paleontology, No. 6, p. 127-136.

Schlanger, S.O., AND Jenkyns, H.C., 1976, Cretaceous oceanic anoxic events: causes and consequences: Geologie en Mijnbouw, v. 55, p. 179-184.

Schlanger, S.O., Arthur, M.A., Jenkyns, H.C., and Scholle, P.A., 1987, The CenomanianTuronian Oceanic Anoxic Event, I. Stratigraphy and distribution of organic carbon-rich beds and the marine $\delta^{13} \mathrm{C}$ excursion, in Brooks, J., and Fleet, A.J., eds., Marine Petroleum Source Rocks: Geological Society of London, Special Publication 26, p. 371-399.

Schiffelbein, P., And Dorman, L., 1986, Spectral effects of time-depth nonlinearities in deep sea sediment records: a demodulation technique for realigning time and depth scales: Journal of Geophysical Research, v. 91, p. 3821-3835.

SCHWARZACHER, W., 1987, The analysis and interpretation of stratification cycles: Paleoceanography, v. 2, p. 79-95.

Schwarzacher, W., 1994, Cyclostratigraphy of the Cenomanian in the Gubbio District, Italy: a field study, in de Boer, P.L., and Smith, D.G., eds., Orbital Forcing and cyclic sequences: International Association of Sedimentologists, Special Publication 19, p. 87-97.

Slingerland, R., Kump, L., Arthur, M., Fawcett, P., Sageman, B., and Barron, E., 1996, Estuarine circulation in the Turonian Western Interior Seaway of North America: Geological Society of America, Bulletin, v. 108, p. 941-952.

Thomson, D.J., 1982, Spectrum estimation and harmonic analysis: IEEE Proceedings, v. 70, p. $1055-1096$

Thomson, D.J., 1990, Time series analysis of Holocene climate data: London, Royal Society, Philosophical Transactions, v. 330, p. 601-616.

WATKINS, D.K., 1989, Nannoplankton productivity fluctuations and rhythmically bedded pelagic carbonates of the Greenhorn Limestone (Upper Cretaceous): Palaeogeography, Palaeoclimatology, Palaeoecology, v. 74, p. 75-86.

WeEdon, G.P., AND Jenkyns, H.C., 1999, Cyclostratigraphy and the Early Jurassic timescale: data from the Belemnite Marls, Dorset, southern England: Geological Society of America, Bulletin, v. 111, p. 1823-1840.

Yiou, P., Genthon, C., Ghil, M., Jouzel, J., Le Treut, H., Barnola, J., Lorius, C., and KoRotKevitch, Y., 1991, High-Frequency paleovariability in climate and $\mathrm{CO}_{2}$ levels from Vostok ice core records: Journal of Geophysical Research, v. 96, p. 20,365-20,378.

Received 28 August 2000; accepted 24 January 2001.

\section{APPENDIX}

The multi-taper method of harmonic analysis used in this study obtains superior frequency resolution by applying several bias-resistant orthogonal tapers (known as discrete prolate spheroidal sequences or DPSSs) independently to a data series, and performing Fast Fourier transforms on each tapered, evenly sampled data series (Thomson 1982):

$$
y_{k}(f)=\sum_{t=0}^{N-1} v_{t}^{(k)} x_{t} e^{i 2 \pi f t}
$$

where $y_{k}$ is the eigencoefficient (complex Fourier coefficient) of tapered series $k$ at frequency $f, v_{t}^{(k)}$ is the data taper for the $k^{\text {th }}$ DPSS estimate, $N$ is the number of points in the data series, and $x_{t}$ is the data (pixel value, $\% \mathrm{CaCO}_{3}$, etc.) at time $t$. The orthogonality of the $k$ DPSS data tapers supplies statistically independent estimates of the frequency content of the data series. The high-resolution amplitude estimates presented in this study were calculated by performing a least-squares linear regression over the eigencoefficients of the $K$ independent estimates:

$$
\mu(f)=\frac{\sum_{k=0}^{K-1} W_{k}^{*}(0) y_{k}(f)}{\sum_{k=0}^{K-1}\left|W_{k}(0)\right|^{2}}
$$

where $\mu$ is the mean complex amplitude estimate, $K$ is the number of tapers used, $W_{k}(0)$ is the complex Fourier coefficient for taper $\mathrm{k}$ at the zero frequency, and * denotes the complex conjugate. The final real-valued amplitudes were generated by taking the modulus of the complex valued $\mu(f)$. This regression technique determines the amplitude of phase coherent sinusoids at each frequency $f$. The estimator $|\mu(f)|$ is also known as the "line", "amplitude", or "first moment" spectrum.

Measurement of the statistical significance of the results were then calculated using an $F$-variance ratio test, which compares the variance associated with this least-squares regression model to the residual variance not explained by the model:

$$
F=\frac{(K-1)|\mu(f)|^{2} \sum_{k=0}^{K-1}\left|W_{k}(0)\right|^{2}}{\sum_{k=0}^{K-1}\left|y_{k}(f)-\mu(f) W_{k}(0)\right|^{2}}
$$

Significance of these $F$ values are evaluated at 2 (model) and $2 K$-2 (residual) degrees of freedom. For additional information regarding the MTM technique (harmonic and power spectral analysis), see Thomson (1982, 1990), Park et al. (1987), and Lees and Park (1995). 